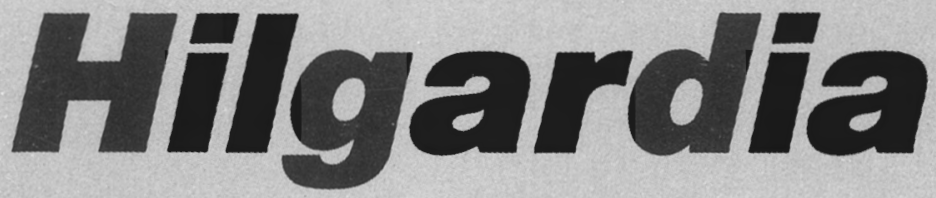

A. JOURNAL OF AGRICULTURAL SCIENCE PUBLISHED BY THE CALIFORNIA AGRICULTURAL EXPERIMENT STATION

Volume 59 - Number 2 - February 1991

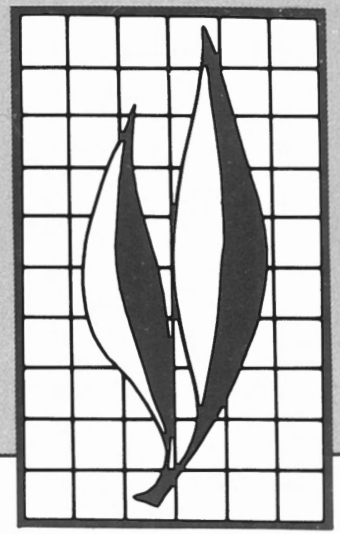

\title{
A Classification System for California's Hardwood Rangelands
}

Barbara H. Allen, Barbara A. Holzman, and Rand R. Evett 


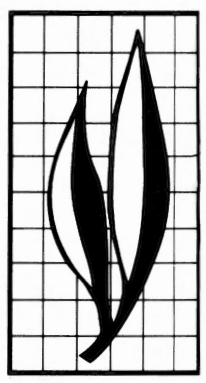

\begin{abstract}
A hardwood rangeland classification system for California is described. The system provides private landowners, land managers, and researchers a unifying framework from which known ecological and management information can be retrieved. Standardization of type names facilitates the exchange of information on hardwood rangelands within and among agencies, landowners, and universities. The dichotomous keys to the type descriptions ensure that the system is field oriented and user-friendly.

The classification system consists of 57 subseries arranged hierarchically within 7 Series. The oak series are defined by the dominant oak species present on the site. A Mixed Oak Series is also defined from sites that contain three or more species of oak at constancies of greater than $30 \%$. This system does not include subseries descriptions for Engelmann or garry oak types.

The classification system was developed from approximately 4,300 plots collected as part of the Vegetation Type Map (VTM) survey conducted during the 1920s-1940s by the USDA Forest Service, Pacific Southwest Forest and Range Experiment Station, and approximately 500 plots collected as part of the Forest Inventory conducted by

\title{
THE AUTHORS:
}

Barbara H. Allen is an Assistant Professor in the Department of Forestry and Resource Management, University of California, Berkeley.

Barbara A. Holzman is a Graduate Research Assistant in the Department of Forestry and Resource Management, University of California, Berkeley.

Rand R. Evett is a Graduate Research Assistant in the Department of Forestry and Resource Management, University of California, Berkeley. 


\section{A Classification System for California's Hardwood Rangelands ${ }^{1}$}

\section{INTRODUCTION}

HARDwOod RANGelands occupy approximately 3 million hectares in California. They occur in 52 of the State's 58 counties, and span fully eight degrees of latitude west of the Sierra Nevada (Mayer et al. 1986). As might be expected in a state as ecologically diverse as California, hardwood rangelands support at least a dozen major tree species and many shrub and herbaceous species that occur in a myriad of combinations.

Since 1980, a number of trends have increasingly focused public attention on hardwood rangelands. These include:

- Continuing population growth that has resulted in conversion of wildlands to urban or semi-urban uses or agriculture.

- Increasing fuelwood use by households and industry.

- Loss of wildlife habitat in hardwood rangelands.

- Increasing oak cutting by ranchers to compensate for declining beef prices.

- Recognition of recruitment problems in riparian, valley oak, Engelmann oak, and blue oak ecosystems.

- Recognition of potential environmental impacts associated with the unregulated removal of hardwood trees.

- Increasing allocation of research effort to study the hardwood rangeland type.

Classification systems of vegetation, soils, habitats, and ecosystems are used by resource managers to group information by some unit. The units are labelled and described so that managers can use them to measure land area, plan treatments, conduct inventories, and aggregate information. Classification units can be broad or site specific, oriented to a single resource or to multiple resources, used locally or widely, or based on single or multiple factors (Allen 1987).

All classifications are artificial, but should describe or distinguish units that exist in nature. Units are typically identified and described to meet a specific need and are distinguished from each other by specific criteria. Natural classification units, such as habitat types or ecological types that are based on climax or potential vegetation, are generally based on relationships among plants, soils, and environment and thus serve a larger number of purposes (Pfister and Arno 1980).

Cover types are groupings of similar vegetation, soils, and environment based on existing vegetation. Some cover types may have occupied an area for long periods, whereas others are temporary occupants of disturbed sites, and through succession gradually give way to more stable cover and ultimately to a potential natural community. Cover type classifications may describe natural vegetation units or be based on single factors, such as a single tree species.

${ }^{1}$ Accepted for publication January 15, 1991 
The hardwood rangeland cover types identified and described in this publication are natural units based on existing vegetation, soils, and environmental factors. They provide landowners and managers with a unifying framework from which known ecological and managerial information can be assessed. In addition, the cover type framework provides the logical units for aggregating information developed through ecological site description efforts, research, and landowner experience. Also, this classification standardizes names to facilitate the exchange of information among agencies, landowners, and universities. The classification system, with keys for field use, also provides landowners and agencies with a tool to improve predictions about site capabilities.

Previous classification efforts have developed descriptions of hardwood rangelands as part of efforts to classify California vegetation (Weislander 1935; Jensen 1947; Munz and Keck 1968; Cheatham and Haller 1975; Barbour and Major 1988; Eyre 1980; Paysen et al. 1980; Passof et al. 1985; and Holland 1986, to name a few). Such cover type descriptions have varying amounts of ecological information, and provide reasonable potential for establishing an hierarchical framework. For example, Eyre (1980) describes four hardwood cover types: California Black Oak (SAF 246), Canyon Live Oak (SAF 249), Blue Oak-Foothill Pine (SAF 250), and California Coast Live Oak (SAF 255). Griffin (1977) provides additional information on oak woodlands in his description of seven types: foothill woodland, valley oak, blue oak, north slope, interior live oak, Engelmann oak, and coast live oak.

However, none of the existing hardwood rangeland classification systems provides a statewide, ecologically based, unifying framework with keys to identify types. Our classification of California hardwood rangelands provides that framework.

The objectives in developing this classification system were to:

1. Develop rangeland cover type descriptions for California's hardwood rangelands, which would allow landowners, advisory agencies, and resource managers to classify and map hardwood rangelands.

2. Examine and incorporate current ecological and managerial information in rangeland cover type descriptions, as available.

3. Provide dichotomous keys for field identification of cover types by local landowners, researchers, and resource managers.

4. Develop hierarchical links, based on cover types, that will serve as a unifying framework and allow application, in general format, to hardwood rangelands throughout the state.

5. Provide a plan for a statewide hardwood rangeland data base, by providing methodology for further evaluation, testing, and refinement of thecover typeclassification.

\section{METHODS}

The development of the classification system was accomplished through a series of steps. Although three data bases were used (table 1), the classification structure relies most heavily on original field plots from the Vegetation Type Map (VTM) project taken during the 1920s and 1930s.

Initially, the USFS Pacific Northwest (PNW) Station's Forest Inventory (FI) plots were examined to identify major hardwood rangeland types throughout the state. The forest inventory plots were collected throughout California by Charles Bolsinger of 
TABLE 1. NUMBER OF PLOTS BY DATA BASE WITHIN EACH COUNTY

\begin{tabular}{|c|c|c|c|c|c|c|c|}
\hline \multirow[b]{2}{*}{ County } & \multicolumn{3}{|c|}{ Data base } & \multirow[b]{2}{*}{ County } & \multicolumn{3}{|c|}{ Data base } \\
\hline & $\begin{array}{c}\text { Forest } \\
\text { Inventory }\end{array}$ & $\begin{array}{c}\text { Soil/ } \\
\text { veg }\end{array}$ & VTM & & $\begin{array}{c}\text { Forest } \\
\text { Inventory }\end{array}$ & $\begin{array}{c}\text { Soil/ } \\
\text { veg }\end{array}$ & VTM \\
\hline Alameda & 2 & - & 38 & Orange & - & - & 9 \\
\hline Alpine & - & - & - & Placer & 15 & - & 69 \\
\hline Amador & 10 & - & 83 & Plumas & 8 & 2 & 20 \\
\hline Butte & 26 & 9 & 30 & Riverside & 1 & - & 7 \\
\hline Calaveras & 22 & 10 & 314 & Sacramento & - & - & 7 \\
\hline Colusa & - & - & - & San Benito & 4 & - & 155 \\
\hline Contra Costa & 2 & - & 57 & San Bernadino & 1 & - & 69 \\
\hline Del Norte & 15 & 3 & - & San Diego & 6 & - & 29 \\
\hline El Dorado & 25 & - & 269 & San Francisco & 8 & - & - \\
\hline Fresno & 10 & 11 & 56 & San Joaquin & 1 & - & 9 \\
\hline Glenn & - & 3 & - & San Luis Obispo & 6 & - & 487 \\
\hline Humboldt & 136 & 10 & - & San Mateo & 6 & - & 57 \\
\hline Imperial & - & - & - & Santa Barbara & - & - & 143 \\
\hline Inyo & - & - & - & Santa Clara & 6 & - & 343 \\
\hline Kern & 14 & - & 68 & Santa Cruz & 11 & - & 109 \\
\hline Kings & - & - & 6 & Shasta & 71 & 21 & 242 \\
\hline Lake & 7 & 3 & - & Sierra & 3 & - & 21 \\
\hline Lassen & 6 & - & - & Siskiyou & 28 & - & 2 \\
\hline Los Angeles & - & - & 20 & Solano & - & - & 23 \\
\hline Madera & 5 & - & 40 & Sonoma & 33 & 2 & 13 \\
\hline Marin & 1 & - & 16 & Stanislaus & 1 & - & 42 \\
\hline Mariposa & 9 & - & 297 & Sutter & - & - & 25 \\
\hline Mendocino & 133 & 3 & 16 & Tehama & 18 & 21 & 3 \\
\hline Merced & - & - & 19 & Trinity & 33 & 1 & - \\
\hline Modoc & 1 & - & - & Tulare & 9 & 1 & 24 \\
\hline Mono & 2 & - & - & Tuolumne & 13 & 1 & 468 \\
\hline Monterey & 5 & - & 360 & Ventura & - & - & 34 \\
\hline Napa & 9 & - & 50 & Yolo & 1 & - & - \\
\hline Nevada & 11 & - & 89 & Yuba & - & - & - \\
\hline
\end{tabular}

PNW, and his field crews. The plot records contain detailed information on species composition, as well as information on tree growth, and environmental conditions, such as elevation, slope, and aspect. The plot data for the state were received on floppy disks and subsequently reduced to approximately 725 plots containing Quercus species. Most of the oak plots were distributed in the northwest portion of the state, although a fair number were found in the northern Sierra Nevada (table 1).

The second data set was supplied by the Soil Vegetation Survey (SVS). This data set had approximately 127 records containing information on species composition and environmental variables. This set was recoded to standardize codes between the FI plots and the SVS plots. Then both data sets were combined for joint analyses. The distribution of SVS plots is noted in table 1.

Finally, field plot records from the VTM project were used as the basis for classification of hardwood rangeland cover types. The plots were collected as part of the statewide effort to map vegetation (Jensen 1947). The plot records contain information on understory plant species cover, tree stand structure (number per diameter class), elevation, slope, aspect, parent material, and other environmental variables. For trees greater than $10 \mathrm{~cm}$ at breast height $(137 \mathrm{~cm}$ or $4.5 \mathrm{feet})$, information was collected on 
TABLE 2. DATA ELEMENTS CONTAINED WITHIN A SPECIFIC DATA BASE*

\begin{tabular}{|c|c|c|c|}
\hline Variable & $\begin{array}{c}\text { Forest } \\
\text { Inventory } \\
(\text { PNW) }\end{array}$ & $\begin{array}{c}\text { Soil/veg } \\
\text { survey } \\
\text { (SVS) }\end{array}$ & $\begin{array}{c}\text { Vegetation } \\
\text { type map } \\
\text { (VTM) }\end{array}$ \\
\hline Quad & $\mathrm{x}$ & $\mathbf{x}$ & $\mathrm{x}$ \\
\hline Plot & $\mathrm{X}$ & $\mathrm{X}$ & $\mathrm{X}$ \\
\hline County & $\mathbf{x}$ & $\mathrm{x}$ & $\mathrm{x}$ \\
\hline Township & $\mathrm{x}$ & $\mathrm{X}$ & $\mathbf{X}$ \\
\hline Range & $\mathrm{x}$ & $\mathrm{X}$ & $\mathrm{X}$ \\
\hline Section & $\mathrm{x}$ & $\mathbf{x}$ & $\mathrm{X}$ \\
\hline Plot date & - & - & $\mathrm{x}$ \\
\hline Elevation & $\mathbf{x}$ & $\mathrm{X}$ & $\mathbf{x}$ \\
\hline Aspect & $\mathrm{x}$ & $\mathrm{X}$ & $\mathrm{X}$ \\
\hline Slope & $\mathbf{x}$ & $\mathbf{X}$ & $\mathrm{X}$ \\
\hline Precipitation & - & $\mathbf{x}$ & $\mathrm{X}$ \\
\hline Topography & $\mathrm{X}$ & $\mathrm{x}$ & - \\
\hline Soil series & - & $\mathrm{x}$ & - \\
\hline Parent material & - & $\mathbf{x}$ & $\mathbf{X}$ \\
\hline Permeability & $\mathrm{x}$ & $\mathbf{x}$ & - \\
\hline Penetrability & - & - & $\mathrm{X}$ \\
\hline Drainage & - & $\mathrm{X}$ & - \\
\hline Surface stoniness & - & $\mathrm{x}$ & - \\
\hline Exposed bedrock & - & $\mathbf{X}$ & - \\
\hline Plant species code & $\mathbf{X}$ & $\mathrm{x}$ & $\mathrm{X}$ \\
\hline$\%$ species cover & $\mathrm{X}$ & $\mathbf{x}$ & $\mathrm{x}$ \\
\hline Layer & - & $\mathrm{X}$ & $\mathrm{X}$ \\
\hline DBH class & $\mathrm{X}$ & - & $\mathrm{X}$ \\
\hline Year since burn & - & - & $\mathbf{s}$ \\
\hline Site index & - & - & $\mathbf{s}$ \\
\hline Species Ht & $\mathrm{X}$ & - & s \\
\hline Number of plots & 725 & 127 & $4,300+$ \\
\hline
\end{tabular}

$* \mathrm{X}=$ has information, $-=$ no data, $\mathrm{s}=$ spotty

$1 / 5$-acre $(0.08$ ha) plots. Table 2 compares the variables contained in the three data sets. All plant species were coded using national standard codes based on the first two letters of the genus and first two letters of the species (Powell 1987). A number is given after the four letters to distinguish between species having the same letter code. All plant species scientific and common names, and corresponding codes, are listed in appendix 1 .

Approximately 4,300 plots from the VTM data set contained Quercus species. The plots were widely distributed in oak types throughout the state (table 1), although few plots were taken in Engelmann oak or garry oak types. Again, the first step standardized the coding of the VTM plots to match the FI and SVS plots, and converted the plots from paper records to a computerized data matrix. Plant species on VTM plots were originally recorded using an old and currently unused system, and thus had to be carefully recoded to current national standard plant species codes. This process took approximately 7 months to search the more than 8,000 paper VTM records, pull out plots with oaks, find the species name and convert old codes to new, and computerize 
and clean the data base. The original VTM plots are on file at the Jepson Herbarium, University of California, Berkeley.

Once the data bases were established on RBASE (1985), analyses began. Later, the data base was converted to DBASE IV (1988) to facilitate manipulation of the large number of plot records. A computer programmer worked part-time on the project and wrote specific PASCAL programs to facilitate downloading of plot records to use in different analyses packages.

The FI/SVS and VTM data sets were analyzed separately and then compared visually. Initially, both data sets were treated the same as described below. In later analyses, only the VTM data set was used because it was the most geographically comprehensive.

The analysis strategy was to first look for patterns in plant species distribution to be able to identify plant communities. TWINSPAN, Two-Way Indicator Species Analysis (Hill 1979a), was the analytical tool used in the first step. TWINSPAN uses species percent cover to compare plots and species. Because the VTM data set contains percent cover values for shrub and herbaceous species, but not for trees, basal area was calculated from available stand structure information to serve as an index of cover for trees. Basal area is the cross-sectional area of a tree bole at 4.5 feet $(137 \mathrm{~cm})$, and thus is a reasonable index of the site occupancy of specific tree species. TWINSPAN cut levels were adjusted accordingly to incorporate "cover" values of greater than $100 \%$. The six cut levels used in analysis were $2,5,15,25,75$, and 95 .

Because of the large number of plots in the VTM data set and the plot limits of the TWINSPAN program, the plots were initially divided into four large geographical regions: the central-south coast range, the lower elevation central and southern Sierra Nevada, the higher elevation central and northern Sierra Nevada, and the northern Sierra, Klamath Mountains, and north coast range. TWINSPAN was used to examine each of these geographic regions and the FI/SVS data sets independently.

Initial analysis indicated that patterns in plant communities at the Series level, based on dominance of individual oak species, existed. The FI/SVS data set consisted of primarily tanoak, some garry oak, and conifer types and thus was not analyzed further, until the VTM set was analyzed in detail. The VTM data sets (four geographical regions) were then reanalyzed using TWINSPAN, combining plots that contained similar oak species dominance regardless of their original geographical region.

At this stage, DECORANA, Detrended Correspondence Analysis (Hill 1979b), was used to array plots from the vegetation types distinguished in TWINSPAN to examine relationships between types through environmental gradients. Simultaneously, regression and analysis of variance in SPSSPC + , Statistical Package for the Social Sciences (Norusis 1986,1988), were used to evaluate the environmental characteristics of the types that could be used to explain the community distribution. Major oak series were distinguished, including coast live oak, interior live oak, blue oak, black oak, valley oak, scrub oak, and a mixed oak series that contained three or more oak species.

A period of continuous feedback analysis began as each oak series was reanalyzed independently using TWINSPAN, DECORANA, and regression analysis techniques, and plots were juggled between types making individual types more homogeneous. One-way ANOVA (Norusis 1986) was used to compare mean differences in species basal area or cover, and other environmental attributes between types. Differences were considered significant at $\mathrm{p}<0.05$. Finally, several individual counties were analyzed separately to see if the same patterns in community types would hold true for localized areas. 
Plant species coding problems became apparent throughout the analyses as unusual "types" appeared. Often, the species codes were traced back to the original VTM plot cards, and errors in identification were corrected. The unusual type plots were then correctly classified. However, other errors in the data set originated from original data collection and coding problems, our conversion of old codes to new plant species codes, and data entry errors. Any impact on the classification system from coding errors was minimized by field testing, reanalysis, the large number of plots, and common sense.

Plant community cover type keys were constructed for each oak series. The primary objective of key construction was to develop an accurate, easy-to-use key to aid field users in the correct identification of cover types. Thus, a few characteristic species and environmental attributes were used in the keys for each series. A key to the series was also constructed.

Descriptions were written for each rangeland cover type or subseries. Each description contains the type name, number of plots used to describe the type, location information, environmental setting, and plant species. Additionally, a stand table was given for the tree species. Because the descriptions were founded on old plot data, the original units were used, without conversion to metric units.

Keys and descriptions were field tested. Difficulties in use of the keys, format problems in the description, and errors in plant species coding were evaluated, discussed, and corrected as appropriate. This process often resulted in additional analyses of several subseries within an oak series. The analyses may have included TWINSPAN and DECORANA analyses, and combining or splitting of types.

The classification system was reviewed by a number of hardwood experts as well as individuals unfamiliar with hardwood rangeland ecosystems in several areas in the state. The review consisted of a discussion of the classification structure, instructions on how to use the system and keys, and field review and evaluation of the keys and type descriptions.

After field review, the classification was refined as appropriate by reworking the keys and carrying out additional analysis if necessary. The process of field review took place from January through May 1989.

\section{RESULTS}

\section{The Cover Types}

The hardwood rangelands of California are divided into 57 subseries within 7 Series. The oak series are defined by the dominant oak species present on the site. A Mixed Oak Series is also defined by sites containing three or more species of oak at constancies of $30 \%$ or more. To facilitate user-friendliness, a subseries may be listed in two Series and can be keyed from either Series' key.

The term subseries is used to describe the appropriate hierarchical level of the described hardwood types. Since site-specific response to management has not been used as a criterion in classification, nor was a complete species list (including all herbaceous species) available, the cover types described in this report cannot be called ecological types. However, the types or subseries described incorporate more ecological information than any other system to date, and are thus at a finer level of resolution than Series. Subseries, though unused before in the literature, is the appropriate classification level. 
The rangeland cover type names are composed of the dominant species of the tree, shrub, or herbaceous layer. The species having the greatest constancy (presence) across all plots representing the type is used in the name. A slash (/) is used to separate species of different life forms, and a dash (-) is used to separate species of the same life form. Scientific species names, common names, and codes come from Munz and Keck (1968) and Powell (1987).

The seven Series and their associated subseries are listed in table 3.

TABLE 3. HARDWOOD RANGELAND SUBSERIES ARRANGED BY SERIES, AND GEOGRAPHIC OR ENVIRONMENTAL LOCATION WITHIN SERIES*

\section{QUAG SERIES}

Lower Elevation, Mesic Subseries

1. Coast Live Oak/Blackberry/Bracken Fern (781 ft) QUAG/RUVI2/PTAQ

2. Coast Live Oak-Madrone/Hazelnut-Blackberry $(870 \mathrm{ft})$ QUAG-ARME3/COCO5-RUVI2

3. Coast Live Oak/Poison Oak $(910 \mathrm{ft})$ QUAG/RHDI

Upper Elevation, Mesic Subseries

4. Coast Live Oak/Ocean Spray-Snowberry (1300 ft) QUAG/HODI-SYRI

5. Coast Live Oak/Coffeeberry-Toyon (1250 ft) QUAG/RHCA2-HEAR2

6. Coast Live Oak-California Bay/Toyon-Scrub Oak (1318 ft) QUAG-UMCA1/HEAR2-QUDU2

7. Coast Live Oak-Maple/Coffeeberry-Ocean Spray (1695 ft) QUAG-ACMA/RHCA2-HODI

Middle Elevation, Xeric Subseries

8. Coast Live Oak/Poison Oak/Grass (1018 ft) QUAG/RHDI/GRASS

9. Coast Live Oak/Toyon-Poison Oak ((1205 ft) QUAG/HEAR2-RHDI

10. Coast Live Oak/Coast Sagebrush/Grass (1005 ft) QUAG/ARCA7/GRASS

11. Coast Live Oak/Chamise-Black Sage (1100 ft) QUAG/ADFA-SAME4

12. Coast Live Oak/Grass (1050 ft) QUAG/GRASS

13. Coast Live Oak (1178 ft) QUAG

14. Blue Oak-Coast Live Oak/Grass (1054 ft) QUDO-QUAG/GRASS

15. Coast Live Oak/Toyon/Grass (1312 ft) QUAG/HEAR2/GRASS

\section{QUDO SERIES}

Coast Range Subseries

1. Blue Oak-Valley Oak-Coast Live Oak/Grass (1567 ft)

QUDO-QULO-QUAG/GRASS

2. Blue Oak-Valley Oak/Grass (1477 ft) QUDO-QULO/GRASS 
TABLE 3. (Continued)

QUDO SERIES (Continued)

Coast Range Subseries

3. Blue Oak-Coast Live Oak/Grass (1054 ft) QUDO-QUAG/GRASS

Sierra Nevada Subseries

4. Blue Oak-Foothill Pine/Whiteleaf Manzanita/Grass ( $1388 \mathrm{ft}$ ) QUDO-PISA2/ARVI3/GRASS

Coast Range and Sierra Nevada Subseries

5. Blue Oak/Grass (1296 ft) QUDO/GRASS

6. Blue Oak-Understory Blue Oak/Grass ( $1489 \mathrm{ft}$ ) QUDO-UQUDO/GRASS

Coast Range and Sierra Nevada Subseries

7. Blue Oak-Foothill Pine/Grass (1749 ft) QUDO-PISA2/GRASS

8. Blue Oak-Foothill Pine/Wedgeleaf Ceanothus-Mt. mahogany (2526 ft) OUDO-PISA2/CECU2-CEBE2

9. Blue Oak/Haplopappus ( $2288 \mathrm{ft}$ ) QUDO/HALI

10. Blue Oak-Interior Live Oak/Grass ( $1500 \mathrm{ft}$ ) QUDO-QUWI/GRASS

11. Blue Oak/Wedgeleaf Ceanothus/Grass (1752 ft) QUDO/CECU2/GRASS

12. Interior Live Oak-Blue Oak-Foothill Pine (1534 ft) QUWI-QUDO-PISA2

QULO SERIES

Upper Elevation Subseries

1. Valley Oak/Grass (2253 ft) QULO/GRASS

2. Black Oak-Valley Oak/Grass (2375 ft) QUKE-QULO/GRASS

Lower Elevation Subseries

3. Coast Live Oak-Valley Oak/Poison Oak (1101 ft) QUAG-QULO/RHDI

4. Mixed Oak-Valley Oak/Poison Oak-Coffeeberry (1443 ft) MO-QULO/RHDI-RHCA2

5. Valley Oak-Coast Live Oak/Grass (1318 ft) QULO-QUAG/GRASS

6. Blue Oak-Valley Oak/Grass (1477 ft) QUDO-QULO/GRASS

\section{QUWI SERIES}

Coast Range and Sierra Nevada Subseries

1. Interior Live Oak-Madrone/Poison Oak (1493 ft) QUWI-ARME3/RHDI

2. Interior Live Oak-Blue Oak-Foothill Pine (1533 ft) QUWI-QUDO-PISA2

Sierra Nevada Subseries

3. Interior Live Oak/Yerba Santa/Grass (2120 ft) QUWI/ERCA6/GRASS 
TABLE 3. (Continued)

QUWI SERIES (Continued)

Coast Range Subseries

4. Interior Live Oak-Foothill Pine/Manzanita (1144 ft) QUWI-PISA2/ARMA3

5. Interior Live Oak/Toyon (1855 ft) QUWI/HEAR2

6. Interior Live Oak/Whiteleaf Manzanita (1780 ft) QUWI/ARVI3

QUKE SERIES

Coast Range Subseries

1. Black Oak-Madrone-Coast Live Oak (1293 ft) QUKE-ARME3-QUAG

2. Mixed Oak-Coast Live Oak/Poison Oak (1465 ft) MO-QUAG/RHDI

3. Black Oak-Coast Live Oak-Beach Pine/Ocean Spray (1691 ft) QUKE-QUAG-PICO1/HODI

4. Black Oak-Valley Oak/Grass (2375 ft) QUKE-QULO/GRASS

Sierra Nevada Subseries

5. Black Oak/Poison Oak-Calif. Storax/Grass-nut (1484 ft) QUKE/RHDI-STOFC/BRLA2

6. Black Oak/Deerbrush-Poison Oak/Bracken Fern (2527 ft) QUKE/CEIN3-RHDI/PTAQ

7. Black Oak/Deerbrush (3435 ft) QUKE/CEIN3

8. Black Oak/Greenleaf Manzanita ( $5647 \mathrm{ft}$ ) QUKE/ARPA9

Coast Range and Sierra Nevada Subseries

9. Black Oak/Poison Oak (2486 ft) QUKE/RHDI

10. Black Oak/Poison Oak/Grass (2746 ft) QUKE/RHDI/GRASS

11. Black Oak-Canyon Live Oak/Poison Oak (2963 ft) QUKE-QUCH2/RHDI

12. Canyon Live Oak-Black Oak (3231 ft) QUCH2-QUKE

13. Black Oak/Grass (4193 ft) QUKE/GRASS

QUDU2 SERIES

1. Scrub Oak-Blue Oak/Grass (1400 ft) QUDU2-QUDO/GRASS

2. Scrub Oak/Grass (1369 ft) QUDU2/GRASS

3. Scrub Oak (1427 ft) QUDU2

MIXED OAK SERIES

Sierra Nevada Subseries

1. Interior Live Oak/Toyon (1854 ft) QUWI/HEAR2 
TABLE 3. (Continued)

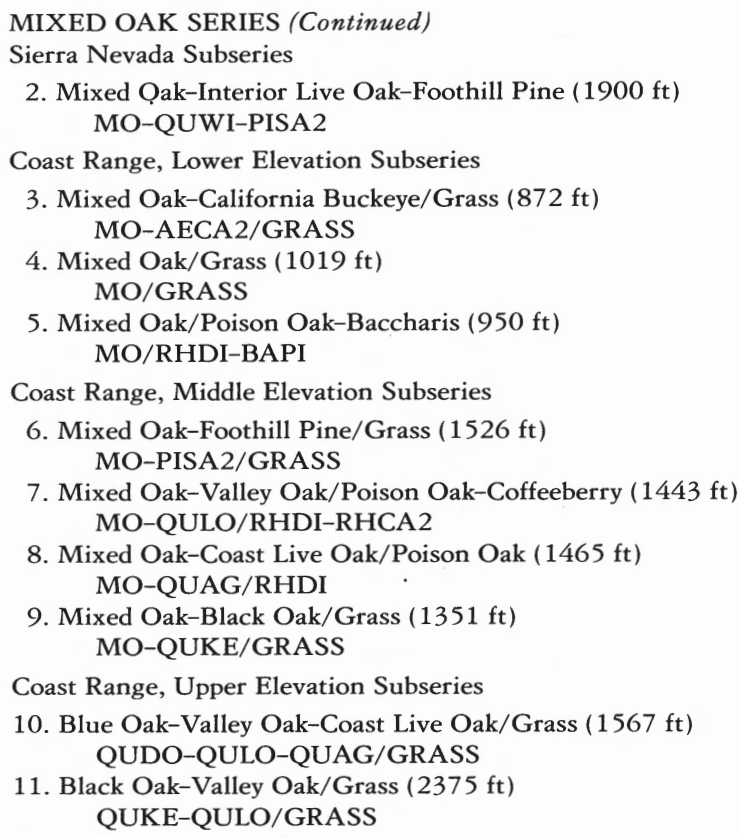

*Hardwood rangeland subseries arranged by Series, and geographic or environmental location within Series. The common name for the subseries is listed first and then the code name. Mean elevation for each subseries is noted in parenthesis. All scientific names are found in appendix 1 . Refer to the text for discussion of each subseries.

\section{The Hardwood Rangeland Cover Type Keys}

The keys to the hardwood rangeland cover types were constructed using both dominant species and species that indicated differences in the environments between types. Attributes of the types that are easily recognizable in the field were used in the keys.

Users must know approximately a dozen plant species to use the keys to the hardwood rangeland subseries. Users should stand in a relatively homogeneous site when applying the keys. If the vegetation is homogeneous over the landscape, then it is appropriate for the user to apply the type label over that landscape. However, if the landscape is heterogeneous, the user should apply the key to the homogenous unit in which he or she is standing.

Since keys are only a tool in identifying the type, users should also read the type description to verify that the type has been correctly identified. If the description does not fit with what the user is seeing on the ground, the person should go back through the key and check alternative routes. The complete hardwood cover type descriptions are available from the Department of Forestry and Fire Protection, Sacramento, California. A comparison overview of the types, including mean basal area estimates, species information, and elevation follows the keys. 


\section{KEY TO THE SERIES}

1a. Stand consists of single Quercus species.

Go to the:

Coast Live Oak Key:

Blue Oak Key:

Valley Oak Key:

Interior Live Oak Key:

Black Oak Key:

Scrub Oak Key:

1b. Stand consists of two or more Quercus species.

2a. Go to the key of the dominant oak species.

2b. If stand consists of three or more oak species, go to:

Mixed Oak Series Key:

\section{KEY TO THE COAST LIVE OAK SUBSERIES}

1a. Coast live oak (QUAG) is the only overstory tree. Understory species are rarely present with total cover that seldom exceeds $25 \%$. Coast live oak basal area is usually high ( $>200 \mathrm{ft}^{2} /$ acre).

Coast Live Oak

1b. Coast live oak may be the only overstory tree present and total understory cover exceeds $25 \%$. Coast live oak basal area is less than $200 \mathrm{ft}^{2} /$ acre.

2a. Understory grass cover generally exceeds $50 \%$.

3a. Blue oak is present.

Blue Oak-Coast Live Oak/Grass

3 b. Blue oak is absent.

Coast Live Oak/Grass

$2 \mathrm{~b}$. Understory grass cover is less than $50 \%$.

4a. The following shrubs are present individually or together in the understory: coffeeberry, ocean spray, blackberry, and hazelnut. Big leaf maple may be present in the tree layer. The shrubs toyon, chamise, coast sagebrush, and black sage are absent. California bay is absent.

5a. Bracken fern is present, baccharis is often present. Big leaf maple, madrone, snowberry, and hazelnut are absent.

Coast Live Oak/Blackberry/Bracken Fern

5b. Bracken fern and baccharis are absent.

6a. Madrone and hazelnut are present. Big leaf maple, ocean spray, and snowberry are absent.

Coast Live Oak-Madrone/Hazelnut-Blackberry 
6b. Madrone and hazelnut are absent. Big leaf maple, ocean spray, and snowberry are present.

7a. Big leaf maple is present. Snowberry is absent.

Coast Live Oak-Maple/Coffeeberry-Ocean Spray

7b. Big leaf maple is absent. Snowberry is present.

Coast Live Oak/Ocean Spray-Snowberry

$4 \mathrm{~b}$. Blackberry, hazelnut, and big leaf maple are absent. Coffeeberry and ocean spray may be present. The shrubs toyon, chamise, coast sagebrush, and black sage may be present. California bay may be present.

8a. Toyon is present. Redberry and California bay may be present. Black sage and coast sagebrush are absent.

9a. Other shrubs and trees are generally absent.

Coast Live Oak/Toyon-Poison Oak

9b. Coffeeberry, redberry, ocean spray, and California bay may be present. Chamise and wedgeleaf ceanothus may be present.

10a. Chamise is present; wedgeleaf ceanothus is often present. Coffeeberry, ocean spray, and California bay are absent.

Coast Live Oak/Toyon/Grass

10b. Chamise and wedgeleaf ceanothus are absent. Coffeeberry, redberry, and California bay are present.

11a. Coffeeberry and redberry are present. California bay and scrub oak are absent.

Coast Live Oak/Coffeeberry-Toyon

11b. Coffeeberry and redberry are absent. California bay and scrub oak are present.

Coast Live Oak-California Bay/Toyon-Scrub Oak

$8 \mathrm{~b}$. Toyon is absent. Redberry and California bay are absent. Black sage and coast sagebrush may be present.

12a. Chamise, black sage, and coast sagebrush are present individually or together.

13a. Coast sagebrush is present with greater than $25 \%$ cover of grasses. Chamise and black sage are absent.

Coast Live Oak/Coast Sagebrush/Grass

13b. Coast sagebrush is absent. Chamise and black sage are present individually or together with less than $25 \%$ cover of grasses.

Coast Live Oak/Chamise-Black Sage 
12b. Chamise, black sage, and coast sagebrush are absent.

14a. Poison oak is the dominant shrub cover. Grass cover is absent.

Coast Live Oak/Poison Oak

14b. Poison oak and grass both have high cover.

Coast Live Oak/Poison Oak/Grass

\section{KEY TO THE BLUE OAK SUBSERIES}

1a. Foothill pine is present in the stand.

2a. Foothill pine and interior live oak are present. Wedgeleaf ceanothus is often present.

3a. Whiteleaf manzanita is present.

Blue Oak-Footbill Pine/Whiteleaf Manzanita/Grass

$3 \mathrm{~b}$. Whiteleaf manzanita is absent or occurs rarely.

4a. Understory interior live oak and blue oak are often present. Other shrubs may be present in the understory.

$5 a$. Wedgeleaf ceanothus averages $18 \%$ cover and is always present. Redberry, poison oak, and other shrubs may be present.

Blue Oak/Wedgeleaf Ceanothus/Grass

5 b. Wedgeleaf ceanothus, if present, averages $8 \%$ cover. Other shrubs are rare.

Blue Oak-Interior Live Oak/Grass

$4 \mathrm{~b}$. Understory interior live oak and blue oak are not present.

Shrubs are rare. Interior live oak is dominant in the stand.

Interior Live Oak-Blue Oak-Foothill Pine

$2 \mathrm{~b}$. Foothill pine is present. Interior live oak is absent. Wedgeleaf ceanothus may or may not be present.

6a. Understory shrubs are rare, averaging $<10 \%$ cover.

Blue Oak-Foothill Pine/Grass

6b. Understory shrubs such as wedgeleaf ceanothus, and/or mountain mahogany, and/or narrowleaf goldenbush are present.

Blue Oak-Foothill Pine/Wedgeleaf Ceanothus-Mt. Mabogany

1b. Foothill pine is absent or rare.

7a. Generally, other oaks are present in the stand with blue oak.

8a. Interior live oak may be present. Basal area of interior live oak is generally $>10 \mathrm{ft}^{2} /$ acre.

9a. The stand is dense with trees averaging $>155$ trees per acre, with basal area $>100 \mathrm{ft}^{2} /$ acre.

Interior Live Oak-Blue Oak-Footbill Pine 
$9 \mathrm{~b}$. The stand is relatively open, with basal area averaging $50 \mathrm{ft}^{2} /$ acre.

10a. Wedgeleaf ceanothus, if present, averages $<10 \%$ cover.

Blue Oak-Interior Live Oak/Grass

10b. Wedgeleaf ceanothus is present and averages $>10 \%$ cover.

Blue Oak/Wedgeleaf Ceanothus/Grass

$8 \mathrm{~b}$. Valley oak and/or coast live oak are present in the stand.

11a. Valley oak is codominant with blue oak.

12a. Coast live oak is absent.

Blue Oak-Valley Oak/Grass

$12 \mathrm{~b}$. Both valley oak and coast live oak are present in the stand.

Blue Oak-Valley Oak-Coast Live Oak/Grass

$11 \mathrm{~b}$. Valley oak is absent.

13a. Coast live oak is present. Coast sagebrush may also be present though shrubs are rare; elevation averages $1,000 \mathrm{ft}$.

Blue Oak-Coast Live Oak/Grass

$13 \mathrm{~b}$. Shrubs are common. Elevation averages $2,500 \mathrm{ft}$.

Blue Oak-Footbill Pine/Wedgeleaf Ceanothus-Mt. Mabogany

7b. Generally blue oak is the only oak present in the stand.

14a. Narrowleaf goldenbush is present.

Blue Oak/Narrowleaf Goldenbush

14b. Narrowleaf goldenbush is absent. Grass is the primary understory species.

15a. Understory blue oaks are present.

Blue Oak-Understory Blue Oak/Grass

15b. Understory blue oaks are absent.

Blue Oak/Grass

\section{KEY TO THE VALLEY OAK SUBSERIES}

1a. Valley oak is the only tree species in the overstory.

Valley Oak/Grass

1b. Valley oak is mixed with other oak species.

2a. Black oak is present.

Black Oak-Valley Oak/Grass

$2 \mathrm{~b}$. Black oak is absent. 
3a. Blue oak is present; coast live oak is rarely present.

Blue Oak-Valley Oak/Grass

3b. Blue oak is sometimes present; coast live oak is present.

4a. Poison oak is present.

5a. Coffeeberry is present.

Mixed Oak-Valley Oak/Poison Oak-Coffeeberry

5 b. Coffeeberry is absent.

Coast Live Oak-Valley Oak/Poison Oak

4b. Poison oak is absent.

Valley Oak-Coast Live Oak/Grass

\section{KEY TO THE INTERIOR LIVE OAK SUBSERIES}

1a. Yerba santa is present.

2a. Yerba santa averages $>20 \%$ cover, grass averages $30 \%$, and overstory tree cover may or may not be present.

Interior Live Oak/Yerba Santa/Grass

$2 \mathrm{~b}$. Yerba santa averages $<20 \%$ cover, whiteleaf manzanita and/or wedgeleaf ceanothus may be common. Interior live oak is present in the overstory.

Interior Live Oak/Whiteleaf Manzanita

1b. Yerba santa is absent or is rare, occurring at $\leq 5 \%$ cover.

3a. Madrone is present; grass is rare.

Interior Live Oak-Madrone/Poison Oak

3b. Madrone is absent.

4a. Grass is present; interior live oak is often present in the understory.

5a. Manzanita is common.

6a. Foothill pine and/or blue oak are present.

Interior Live Oak-Footbill Pine/Manzanita

$6 \mathrm{~b}$. Foothill pine is rare; blue oak is absent.

Interior Live Oak/Whiteleaf Manzanita

5b. Manzanita is not common.

7a. Understory interior live oak may be present, blue oak is common, and toyon is rare.

Interior Live Oak-Blue Oak-Foothill Pine

$7 \mathrm{~b}$. Understory interior live oak and toyon are present. Blue oak is rare.

Interior Live Oak/Toyon

4b. Grass is absent.

Interior Live Oak-Madrone/Poison Oak 


\section{KEY TO THE BLACK OAK SUBSERIES}

1a. Coast live oak, valley oak, canyon live oak, madrone, and/or beach pine are present at $>5 \mathrm{ft}^{2} /$ acre of basal area.

2a. Canyon live oak is present.

3a. Canyon live oak and/or black oak are present in the understory at $>5 \%$ cover. Deerbrush is absent, or present at $<10 \%$ cover. Grass is absent.

Canyon Live Oak-Black Oak

3b. Canyon live oak and/or black oak are absent in the understory, or present at $<5 \%$ cover. Deerbrush is often present at $>10 \%$ cover. Grass is often present.

Black Oak-Canyon Live Oak/Poison Oak

2b. Canyon live oak is absent.

4a. Two of these three species are present: madrone, beach pine, ocean spray.

5a. Two of these three species are present: beach pine, ocean spray, coffeeberry. Toyon is absent.

Black Oak-Coast Live Oak-Beach Pine/Ocean Spray

$5 \mathrm{~b}$. Two of these three species are absent: beach pine, ocean spray, coffeeberry. Toyon is usually present.

Black Oak-Madrone-Coast Live Oak

$4 \mathrm{~b}$. Two of these three species are absent: madrone, beach pine, ocean spray.

6a. Valley oak is present and usually codominant with black oak.

Black Oak-Valley Oak/Grass

6b. Valley oak absent, or present at $<15 \mathrm{ft}^{2} /$ acre of basal area.

Coast live oak is present.

Mixed Oak-Coast Live Oak/Poison Oak

1b. Coast live oak, valley oak, canyon live oak, and beach pine are absent. If present, each species is $<5 \mathrm{ft}^{2} /$ acre of basal area.

7a. Poison oak is present. Usually found in Shasta County or the Coast Range.

8a. Deerbrush, California storax, and/or grass-nut are present. Found mainly in Shasta County.

9a. Bracken fern is present. Grass-nut is absent. Usually above $2,000 \mathrm{ft}$. elevation.

Black Oak/Deerbrusb-Poison Oak/Bracken Fern

9b. Bracken fern is usually absent. Grass-nut and/or California storax are often present. Usually below 2,000 ft. elevation.

Black Oak/Poison Oak-California Storax/Grass-nut 
8b. Deerbrush, California storax, and grass-nut are not present. Found mainly in the Coast Range.

10 a. Grass is $>10 \%$ cover. Foothill pine is often present.

Black Oak/Poison Oak/Grass

$10 \mathrm{~b}$. Grass is $<10 \%$ cover. Foothill pine is absent.

Black Oak/Poison Oak

7b. Poison oak is absent. Usually found in the central and southern Sierra.

11a. Greenleaf manzanita and/or deerbrush are present.

12a. Greenleaf manzanita is present. Deerbrush is absent, or present at $<25 \%$ cover.

Black Oak/Greenleaf Manzanita

12b. Greenleaf manzanita is absent. Deerbrush is present at $>25 \%$ cover.

Black Oak/Deerbrush

11b. Greenleaf manzanita and deerbrush are absent.

13a. Grass is $>5 \%$ cover.

Black Oak/Grass

$13 \mathrm{~b}$. Grass is $<5 \%$ cover.

Black Oak/Poison Oak

\section{KEY TO THE SCRUB OAK SUBSERIES}

1a. Blue oak is present in the overstory. Grass is dominant in the understory.

Scrub Oak-Blue Oak/Grass

1b. Blue oak is absent from the overstory.

2 a. Grass is $>25 \%$ cover.

Scrub Oak/Grass

2b. Grass is $<25 \%$ cover.

Scrub Oak

\section{KEY TO THE MIXED OAK SUBSERIES}

1a. You are located in the Sierra Nevada Range.

2a. Understory interior live oak and/or toyon are present.

Interior Live Oak/Toyon

2b. Understory interior live oak and/or toyon are rare. Foothill pine is common.

Mixed Oak-Interior Live Oak-Footbill Pine 
1b. You are located in the Coast Ranges.

3a. Mean elevation is greater than $2,500 \mathrm{ft}$; black oak and valley oak are common. Black Oak-Valley Oak/Grass

3b. Mean elevation is less than $2,500 \mathrm{ft}$.

4a. Valley oak is the dominant oak species in the mix.

5a. Valley oak and coast live oak are codominants.

6a. Grass, poison oak, and coffeeberry may be present.

Valley and coast live oak have mean basal area $>60 \mathrm{ft}^{2} /$ acre.

Mixed Oak-Valley Oak/Poison Oak-Coffeeberry

6b. Black oak is codominant with coast live oak and valley oak. Grass and poison oak are common.

\section{Mixed Oak-Black Oak/Grass}

5b. Valley and blue oak are codominants. Coast live oak is present. Blue Oak-Valley Oak-Coast Live Oak/Grass

$4 \mathrm{~b}$. Valley oak is not the dominant oak in the species mix. Coast live oak and/or blue oak and/or black oak is dominant.

7a. Coast live oak and black oak are common in the stand. Blue oak is absent or present at low constancy and cover.

8a. Baccharis and/or coffeeberry are common associates. Toyon may be present. Generally low elevation $($ mean $=1,000 \mathrm{ft})$.

Mixed Oak/Poison Oak-Baccharis

$8 \mathrm{~b}$. Baccharis and coffeeberry are very rare. Poison oak is usually present. Generally middle elevation $($ mean $=1,500 \mathrm{ft})$.

Mixed Oak-Coast Live Oak/Poison Oak

$7 \mathrm{~b}$. Blue oak is a common associate in the mixed oak stand.

9a. California buckeye is common. Grass cover averages $95 \%$. Foothill pine is absent or very rare. Generally low elevation.

Mixed Oak-California Buckeye/Grass

9b. California buckeye is not common. Foothill pine may or may not be present.

10a. Foothill pine is absent. Black oak may be present. Low elevation sites.

Mixed Oak/Grass

10b. Foothill pine is present. Black oak is absent. Middle elevation sites.

Mixed Oak-Foothill Pine/Grass 


\section{Overview Description of the Hardwood Rangeland Cover Types}

The overview consists of a comparison of the subseries contained within each Series. Figures 1 through 10 provide a visual comparison of the basal area of the dominant tree species between subseries within a Series. Arbitrarily, $50 \%$ constancy of a specific species was used as the cutoff point for including it on any particular figure. The only exception was for the Mixed Oak Series figure, where the $30 \%$ constancy rule, which defines the type, was employed. Note the differences in scale in the $y$ axis (mean basal area in square feet per acre) between the different Series.

Interpretation of relationships between types within a Series is given. Environmental gradients are discussed, and commonly the types are graphically displayed along an elevational gradient. Subseries whose ranges are strictly Sierra Nevada or Coast Range are discussed separately within the Series. Moisture gradients when apparent are also discussed. Literature is cited comparing the subseries within this classification system to other types and systems.

\section{THE CALIFORNIA COAST LIVE OAK SERIES}

The latitudinal range of coast live oak in California extends from Sonoma County in the north to San Diego County in the south. It is the most coastal of California Quercus, seldom extending more than 60 miles inland from the Pacific Ocean (Griffin and Critchfield 1972). Bolsinger (1988) estimates that the total area of this series in California is 828,000 acres, $79 \%$ of which is in private ownership. Coast live oak stands, on average, contain the greatest basal area of oaks of any of the hardwood rangeland subseries.

The Coast Live Oak Series can be divided into 15 subseries (fig. 1), which can be further separated into mesic and xeric subseries, as they are in the key. There are seven mesic subseries, three of which occur below an average elevation of $910 \mathrm{ft}$ and four above an average elevation of $1,250 \mathrm{ft}$ (table 3). Five of the seven mesic types occupy aspects that predominately face north to northeast, but there are no consistent trends in slope. Species that characterize the mesic subseries include: bracken fern in the herb layer; coffeeberry, blackberry, creambush (ocean spray), snowberry, and hazelnut in the shrub layer; and big-leaf maple, California bay, madrone, and scrub oak in the tree layers (Campbell 1980, Bolsinger 1988).

The low-elevation (below $910 \mathrm{ft}$ ) mesic subseries types are: Coast Live Oak/Blackberry/Bracken Fern, Coast Live Oak-Madrone/Hazelnut-Blackberry, and Coast Live Oak/Poison Oak. The Coast Live Oak/Blackberry/Bracken Fern subseries has significantly less basal area of coast live oak than its other two low-elevation mesic associates (fig. 1). The Coast Live Oak-Madrone/Hazelnut-Blackberry is distinguished from the other two low-elevation mesic types by the presence of madrone, which averages $48 \mathrm{ft}^{2}$ of basal area per acre. All three low-elevation mesic subseries contain poison oak.

Ecological and management information on these low-elevation mesic subseries is scarce, but at least one type has been mentioned in the literature. The Q. agrifoliadominated "oak woodland" described by McBride (1974) in a successional study in the Berkeley Hills is very similar to the Coast Live Oak/Blackberry/Bracken Fern subseries. 


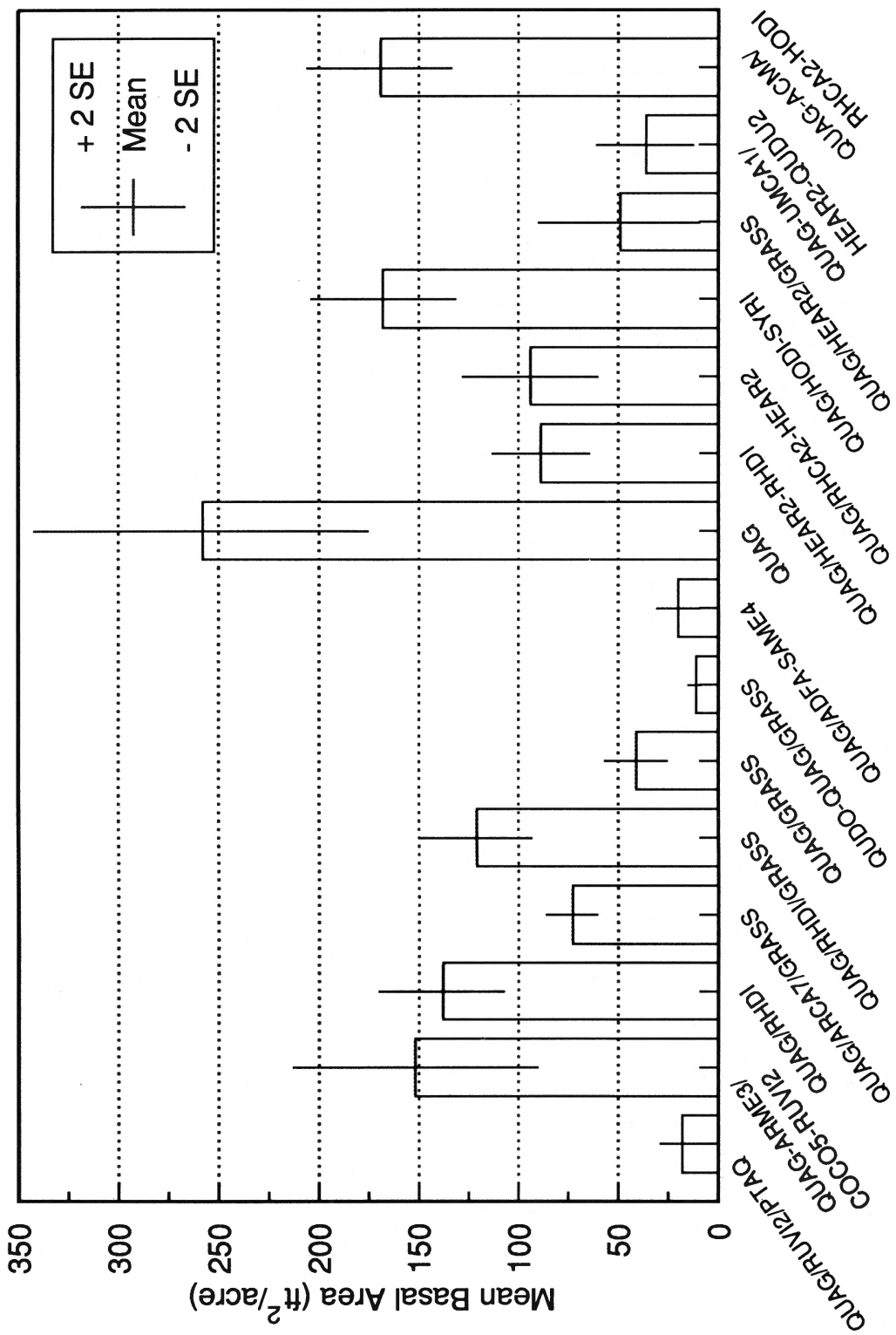

Fig. 1. Comparison of mean coast live oak basal area by coast live oak subseries. Bars represent the 95 percent confidence interval around the mean, approximately \pm 2 standard errors. Note variety in mean basal area between coast live oak types. 
He suggests that in this locale coast live oak woodland is the last sere before a California bay community.

Upper elevation (above 1,250 ft) mesic subseries include: Coast Live Oak/Ocean Spray-Snowberry, Coast Live Oak/Coffeeberry-Toyon, Coast Live Oak-California Bay/ Toyon-Scrub Oak, and Coast Live Oak-Maple/Coffeeberry-Ocean Spray. Campbell (1980) describes a Quercus agrifolia-Toxicodendron diversilobum subcommunity in Santa Barbara County that falls clearly into the Coast Live Oak/Coffeeberry-Toyon subseries both in species composition and environmental setting. The Coast Live Oak-California Bay/Toyon-Scrub Oak subseries has significantly less mean basal area of coast live oak than its other upper elevation mesic associates (fig. 1). The remaining three upper elevation mesic types are distinguished from each other primarily by differences in understory shrubs.

Xeric coast live oak subseries tend to be concentrated in the middle elevations between 1,000 and 1,300 ft. Species typical of this group include: grasses and forbs in the herb layer; toyon, chamise, coast sagebrush, black sage in the shrub layer; and blue oak in the tree layer. Of the eight xeric types, only the Coast Live Oak/Poison Oak/Grass and Coast Live Oak/Toyon-Poison Oak subseries are prevalent on northfacing aspects. These two subseries are moderately productive with a mean basal area of $125 \mathrm{ft}^{2} /$ acre and $90 \mathrm{ft}^{2} /$ acre, respectively (fig. 1). The remaining six types occur on a variety of aspects and, in general, on a variety of slope angles. These subseries include: Coast Live Oak/Coast Sagebrush/Grass, Coast Live Oak/Chamise-Black Sage, Coast Live Oak/Grass, Coast Live Oak, Blue Oak-Coast Live Oak/Grass, and Coast Live Oak/Toyon/Grass. The Coast Live Oak subseries is the densest of all the types with a mean basal area of $260 \mathrm{ft}^{2} /$ acre and little to nothing in the understory.

Wells (1962) provided some of the most detailed information on plant communities in the xeric coast live oak subseries. He cataloged the plant communities on 15 different geologic substrata in the San Luis Obispo Quadrangle. In eight of these communities, coast live oak had a frequency of at least $60 \%$. Of these, the Coast Live Oak/Chamise-Black Sage subseries was represented on at least three different geological substrata, the Coast Live Oak/Toyon/Grass and Coast Live Oak/Coast Sagebrush/ Grass types on two and the Coast Live Oak type on one substratum. Wells discussed in considerable detail the composition of these coast live oak communities in relationship to the interaction of fire and geologic substatum. He provided some useful information on fire, which could be generally applied to several of the subseries.

\section{THE CALIFORNIA BLUE OAK SERIES}

The Blue Oak Series most closely fits the Foothill Woodland described by Griffin (1977). He described a blue oak phase of the Foothill Woodland dominated by blue oak and foothill pine. Associated oak species include coast live oak in the Coast Range, and interior live oak and black oak in the Sierra foothills.

This Series is the most extensive of the hardwood rangeland types in California, covering an estimated 2.9 million acres (Bolsinger 1988). Bolsinger also estimates that $75 \%$ of the Blue Oak Woodland is in private ownership, $14 \%$ in National Forest Systems, and the remaining in other state, county, and miscellaneous federal ownerships.

Blue Oak or Foothill Woodland is divided into 12 blue oak subseries in this classifica- 


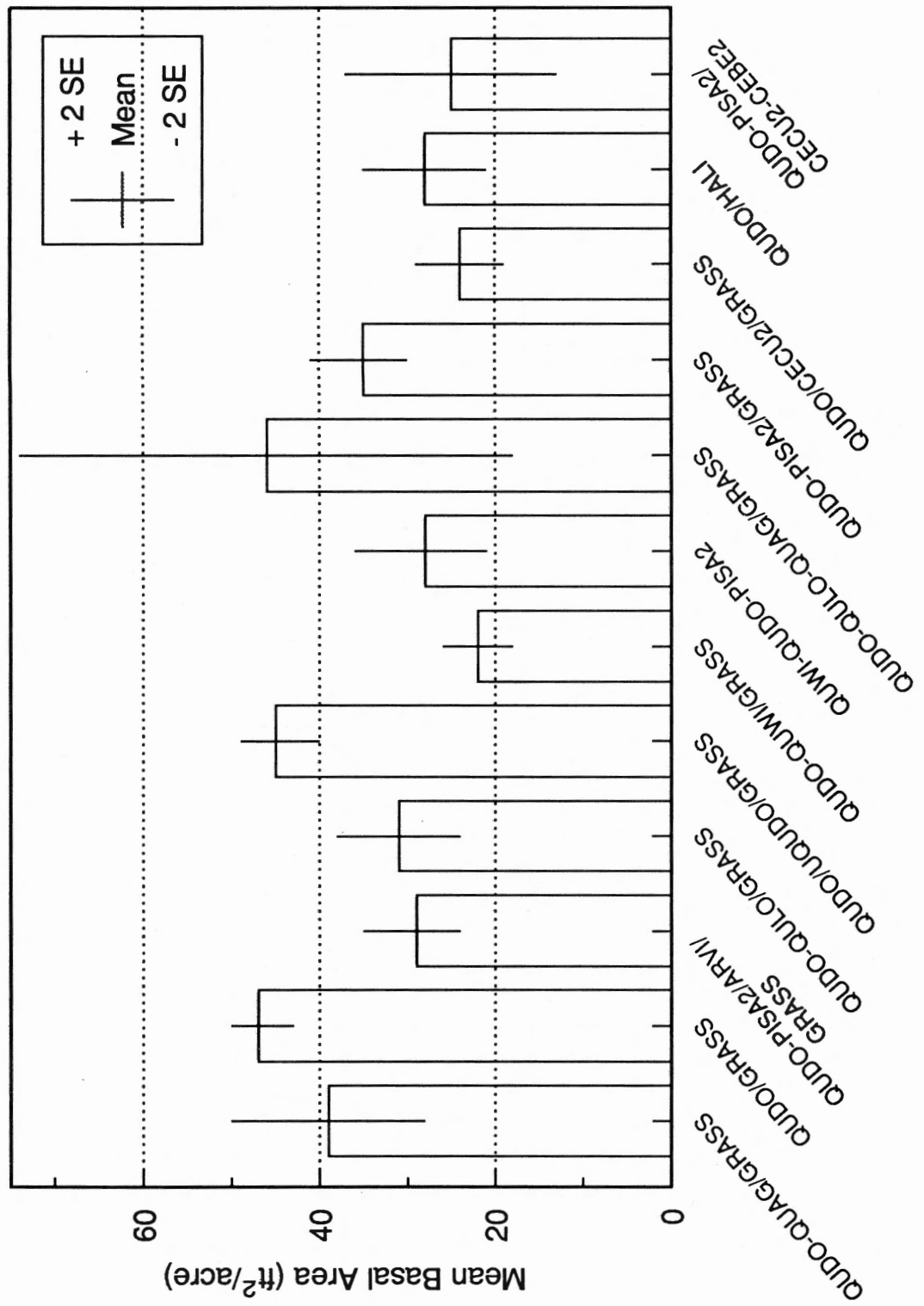

Fig. 2. Comparison of mean blue oak basal area by blue oak subseries. Bars represent the 95 percent confidence interval around the mean, approximately \pm 2 standard errors. Note scale change between figures. 
tion system as part of the Blue Oak Series. The types range in mean elevation from $1,054 \mathrm{ft}$ to $2,526 \mathrm{ft}$ (table 3). Mean basal area of blue oak also varies from an average of $23 \mathrm{ft}^{2} /$ acre to $47 \mathrm{ft}^{2} /$ acre (fig. 2).

Three blue oak subseries are found strictly in the coast ranges, while one type is restricted to the Sierra Nevada foothills. The Sierra Nevada type, Blue Oak-Foothill Pine/Whiteleaf Manzanita/Grass, occurs in Shasta County and in the Sierra Nevada foothills. Common understory associates include whiteleaf manzanita, wedgeleaf ceanothus, poison oak, grass, and other species of manzanita.

The three Coast Range blue oak subseries, Blue Oak-Valley Oak-Coast Live Oak/Grass, Blue Oak-Valley Oak/Grass, and Blue Oak-Coast Live Oak/Grass, are distinguished from each other primarily by their associated oak species, and are named to reflect the codominance of specific oak species. All three coastal types contain high constancies and cover of grass. In addition, the Blue Oak-Coast Live Oak/Grass type also may contain small amounts of coastal species, such as coast sagebrush and honeysuckle. The Blue Oak-Valley Oak-Coast Live Oak/Grass subseries contains the highest basal area of valley oak (averaging $55 \mathrm{ft}^{2} /$ acre) of all the Blue Oak subseries.

The other eight Blue Oak subseries are found ringing the Central Valley in the foothills of the Sierra Nevada and Coast Ranges (table 3). Significant differences exist in mean basal area of blure oak and other associated oak species between the types. The Blue Oak/Grass and Blue Oak-Understory Blue Oak/Grass subseries have the highest blue oak basal areas, averaging $47 \mathrm{ft}^{2} /$ acre and $46 \mathrm{ft}^{2} /$ acre, respectively. Again, the names of the subseries reflect the codominance of species for the type.

Grass cover varies significantly among the types. Types with low grass cover, such as the Blue Oak-Foothill Pine/Wedgeleaf Ceanothus-Mountain Mahogany type, often contain shrubs in the understory. This latter type and the Blue Oak/Narrowleaf Goldenbush also contain high constancies of narrowleaf goldenbush (Haplopappus linearifolius).

\section{THE CALIFORNIA VALLEY OAK SERIES}

Valley oak dominated communities cover approximately $2.7 \%$ of the area of California (Bolsinger 1988). These communities generally occur on the rich loam soils of valleys and foothills below 2,400 ft, and can be found from the foothill woodland of the Central Valley and its borders, to the inner and middle Coast Ranges, to the San Fernando Valley and Los Angeles County. The northern limit of the type reaches from Lakehead above the Sacramento branch of Shasta Lake west to Laytonville in Mendocino County (Griffin and Critchfield 1972).

The Valley Oak Series is comprised of six subseries (fig. 3). All are found in the Coast Ranges and into the Central Valley, except for the Blue Oak-Valley Oak/Grass subseries, which is also found in the Sierra Nevada foothills. Two subseries, Black Oak-Valley Oak/Grass and Valley Oak/Grass, occur at significantly higher mean elevations $(2,375 \mathrm{ft}$ and $2,253 \mathrm{ft}$, respectively) than their other associates, which range in mean elevation from $1,101 \mathrm{ft}$ to $1,477 \mathrm{ft}$ (table 3 ).

The upper elevation subseries can be easily distinguished by the presence of black oak in the Black Oak-Valley Oak/Grass type, and the significantly greater mean basal area of valley oak in the Valley Oak/Grass subseries (fig. 3). The Valley Oak/Grass 


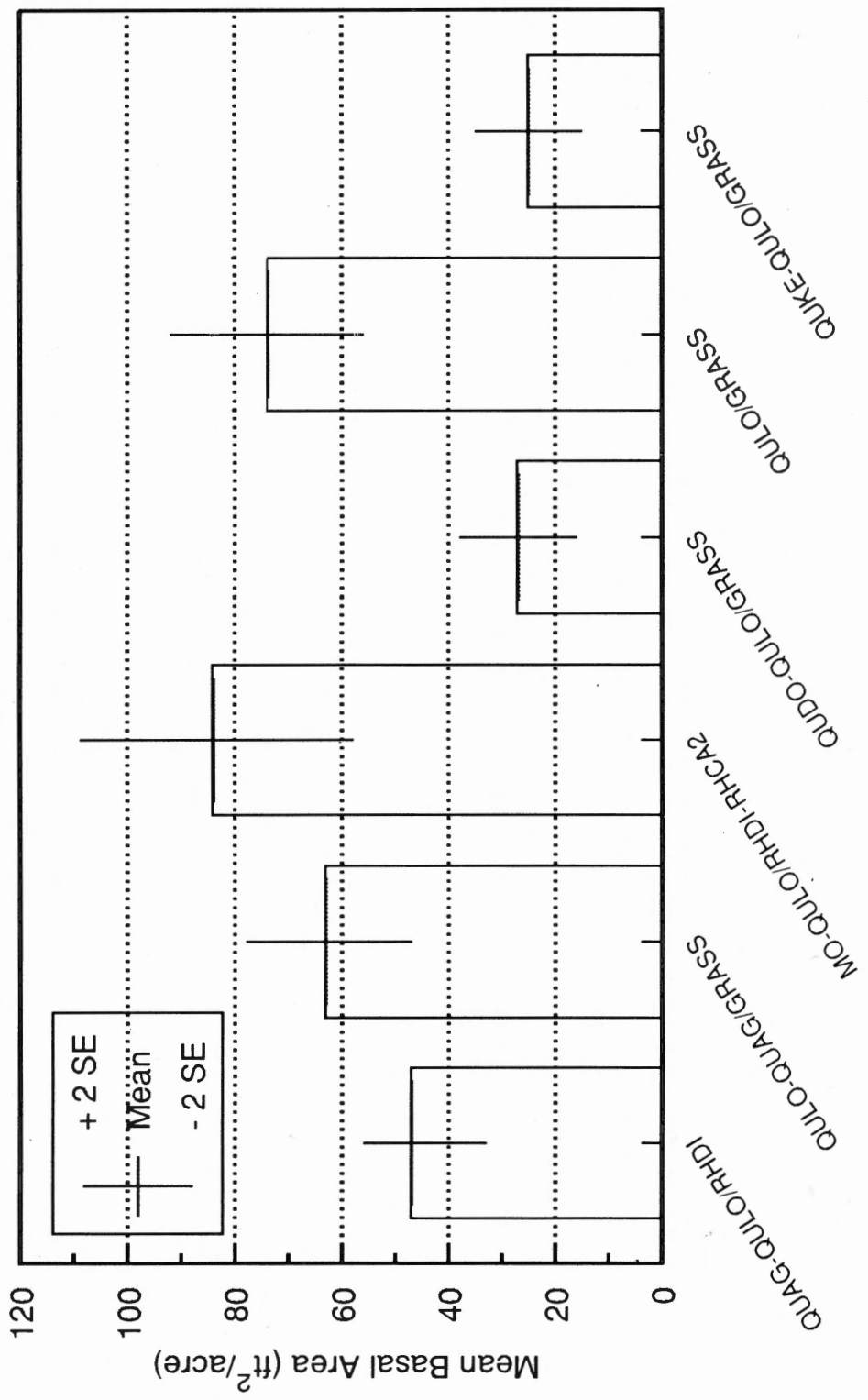

Fig. 3. Comparison of mean valley oak basal area by valley oak subseries. Bars represent the 95 percent confidence interval around the mean, approximately \pm 2 standard errors. 
subseries is also the only valley oak type where valley oak is the primary, dominating Quercus species. The higher elevation subseries occur on similar parent materials, on slopes generally less than $35 \%$, and on all aspects.

The other four valley oak subseries occur at similar elevations (table 3). The Coast Live Oak-Valley Oak/Poison Oak (1,101 ft) and Mixed Oak-Valley Oak/Poison OakCoffeeberry $(1,443 \mathrm{ft})$ subseries have a higher mean basal area of coast live oak than any of the other valley oak subseries, averaging $85 \mathrm{ft}^{2} /$ acre and $122 \mathrm{ft}^{2} /$ acre, respectively. The Mixed Oak-Valley Oak/Poison Oak-Coffeeberry type also contains high mean basal areas of valley oak ( $82 \mathrm{ft}^{2} /$ acre) and blue oak ( $30 \mathrm{ft}^{2} /$ acre) in addition to coast live oak. It keys to the Mixed Oak Series because of the presence of three or more Quercus species at constancies of $30 \%$ or more. The Coast Live Oak-Valley Oak/Poison Oak subseries generally contains less overall basal area than the Mixed Oak-Valley Oak/Poison Oak-Coffeeberry type, although it occurs on wetter sites than the Mixed Oak-Valley Oak/Poison Oak-Coffeeberry subseries.

The Valley Oak-Coast Live Oak/Grass subseries also contains coast live oak, but at lower mean basal area ( $47 \mathrm{ft}^{2} /$ acre) and lower constancy $(84 \%)$ than the other types with coast live oak except for Blue Oak-Valley Oak/Grass, which contains an average of $18 \mathrm{ft}^{2} /$ acre of coast live oak. The Valley Oak-Coast Live Oak/Grass subseries occurs primarily in the southern Coast Ranges along the San Joaquin Valley. Like its other valley oak associates, this type has few understory species other than grass.

Finally, the Blue Oak-Valley Oak/Grass subseries is distinguished from its other associates by the presence of blue oak. It is the driest of the valley oak types, occurring on all aspects, ringing the Central Valley in the foothills of the Sierra Nevada and Coast Ranges. This type was recognized by Griffin (1977) as a phase of the Foothill Woodland containing blue oak.

Grass species occur in all the Valley Oak subseries. However, the Coast Live OakValley Oak/Poison Oak and Mixed Oak-Valley Oak/Coffeeberry types have significantly less cover of grass ( 76 and 54\%, respectively) than any of the other Valley Oak types.

This classification system lacks representatives of the valley oak riparian forest communities. As described by McBride (1974) and Griffin (1973), the valley oak community takes on a strikingly different appearance along the large rivers on the eastside of the Central Valley. Only remnants of this once larger riparian woodland dominated by valley oak, cottonwoods (Populus spp.), willows (Salix spp.), grape (Vitis spp.) and interior live oak (Thompson 1961) now exist.

\section{THE CALIFORNIA INTERIOR LIVE OAK SERIES}

The Interior Live Oak series is comprised of six subseries. Four subseries are found in the Sierra Nevada and foothills, while two types are found in both the Sierra Nevada and Coast Ranges (table 3). Acreage of the Interior Live Oak Series is estimated at 884,000 acres, with about $82 \%$ in private ownership (Bolsinger 1988).

The two subseries, Interior Live Oak-Madrone/Poison Oak and Interior Live OakBlue Oak-Foothill Pine, which are found in both the Sierra Nevada and Coast Ranges, occur at similar mean elevations, $1,493 \mathrm{ft}$ and $1,533 \mathrm{ft}$, respectively (table 3 ). They both contain significantly higher mean basal areas of interior live oak than any other 


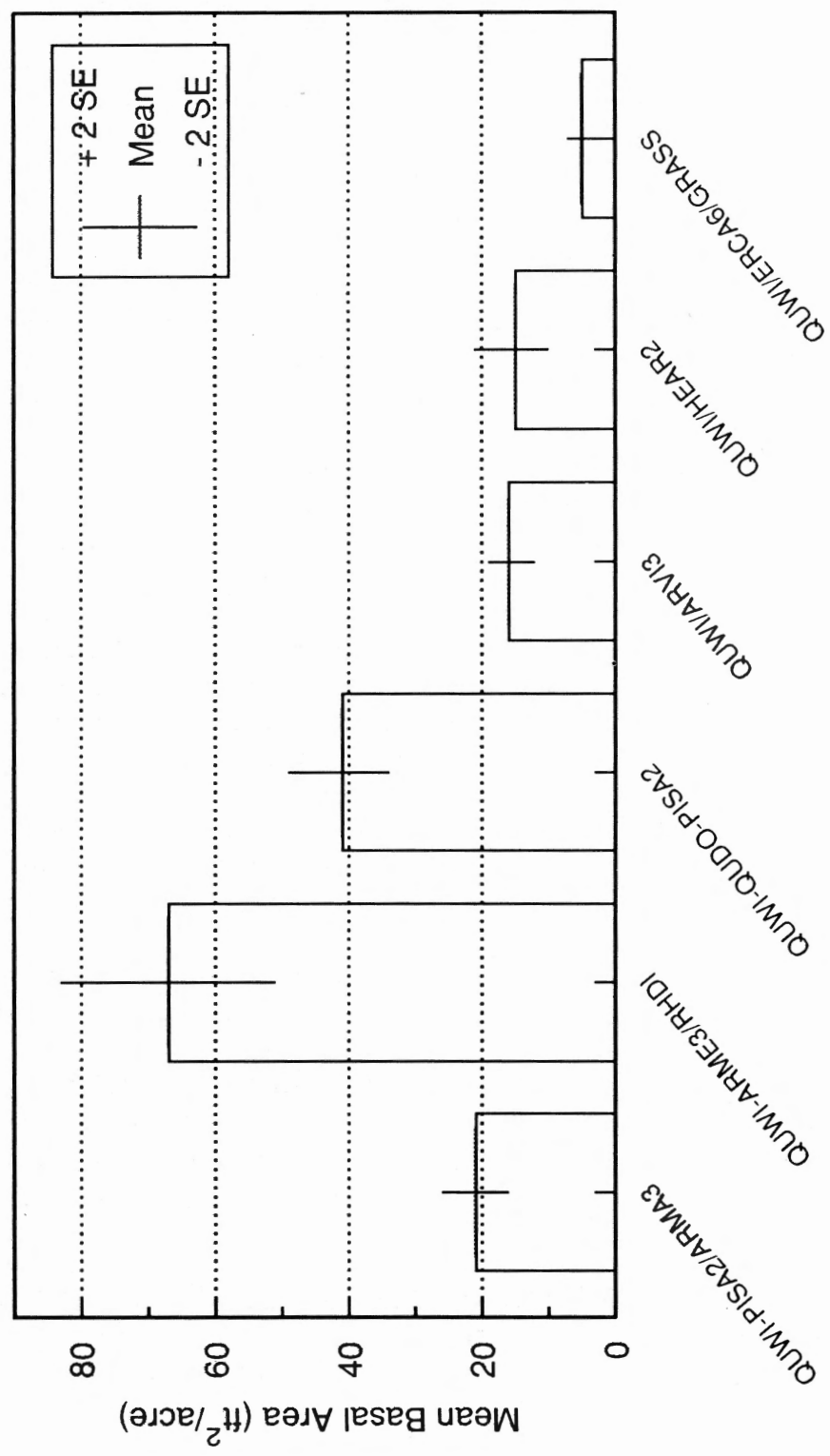

Fig. 4. Comparison of mean interior live oak basal area by interior live oak subseries. Bars represent the 95 percent confidence interval around the mean, approximately \pm 2 standard errors. Note differences in productivity between types. 
interior live oak subseries (fig. 4). Also, the Interior Live Oak-Madrone/Poison Oak has significantly higher mean basal area of interior live oak $\left(68 \mathrm{ft}^{2} /\right.$ acre $)$ than the Interior Live Oak-Blue Oak-Foothill Pine subseries ( $42 \mathrm{ft}^{2} /$ acre).

The Interior Live Oak-Madrone/Poison Oak type can also be distinguished from all its other interior live oak associates by the presence of madrone and the absence of grass. The Interior Live Oak-Blue Oak-Foothill Pine type contains significantly higher mean basal area of blue oak ( $28 \mathrm{ft}^{2} /$ acre $)$ and higher grass cover $(62 \%)$ than any other interior live oak associate.

The two Sierran/Coast Range subseries ring the Central Valley. The Interior Live Oak-Blue Oak-Foothill Pine type is found from Butte to Kern to San Benito Counties. The Interior Live Oak-Madrone/Poison Oak subseries is found from Shasta to El Dorado and Calaveras Counties, and Mendocino to Santa Cruz County.

The Sierra Nevada interior live oak types contain both the highest elevation type, Interior Live Oak/Yerba Santa/Grass at a mean elevation of $2,120 \mathrm{ft}$, and the lowest elevation type, Interior Live Oak-Foothill Pine/Manzanita at 1,144 ft (table 3). The other two Sierra Nevada types occur at mean elevations of $1,780 \mathrm{ft}$ and $1,855 \mathrm{ft}$, for the Interior Live Oak/Whiteleaf Manzanita and Interior Live Oak/Toyon subseries, respectively.

Mean basal areas of interior live oak are significantly different between the interior live oak subseries (fig. 4). The Interior Live Oak-Foothill Pine/Manzanita subseries contains a significantly higher mean basal area of Foothill pine $\left(33 \mathrm{ft}^{2} / \mathrm{acre}\right)$ than its other Sierra Nevada associates as well as more interior live oak than the Interior Live Oak/Yerba Santa/Grass subseries. It occupies sites on granitic, andesitic, serpentine, and hard sedimentary parent materials.

The highest elevation subseries, Interior Live Oak/Yerba Santa/Grass, has a low mean basal area of interior live oak (fig. 4) and the lowest constancy of interior live oak of all the types, although understory interior live oak is common. This type is found from Nevada to Madera Counties, on all aspects on granitic, igneous, or metamorphic parent materials. Yerba santa is the dominant species, in terms of constancy and cover, distinguishing it from its other associates.

The Interior Live Oak/Whiteleaf Manzanita subseries contains significantly more whiteleaf manzanita and significantly less toyon than its other Sierran associates. Finally, the Sierran subseries, Interior Live Oak/Toyon, can be distinguished from the other Sierran types because of its combination of species containing lower blue oak and foothill pine mean basal area, more toyon, and half as much whiteleaf manzanita as its other interior live oak Sierran associates.

Interior live oak is a prominent species in subseries within the Mixed Oak Series, occurring in both Sierra Nevada Mixed Oak subseries and several of the Coast Range Mixed Oak subseries. It is also a common associate in types in the Blue Oak Series, but rarely occurs in the Coast Live Oak, Valley Oak, or Black Oak Series.

Field testing of the interior live oak keys and descriptions resulted in the discovery of at least one "type" that was not described in the classification system. This type occurred in a riparian zone in the Sierra foothills, and was dominated by interior live oak, California bay, and coffeeberry. The type was confined to the riparian zone and abruptly changed to the Interior Live Oak/Toyon subseries on the east-facing slope, and the Interior Live Oak-Blue Oak-Foothill Pine type on the southwest-facing slopes. As more samples are taken in this type, it may be added to the keys and descriptions. 


\section{THE BLACK OAK SERIES}

The Black Oak Series is comprised of 13 subseries (fig. 5). Four subseries are confined to the Coast Ranges, while four are confined to the Sierra. Four subseries are found in both the Coast Ranges and the Sierra, and one is found in both the Coast Ranges and the Transverse Range (table 3).

Types that occur only in the Coast Ranges are generally lower in elevation than other types. The Black Oak-Madrone-Coast Live Oak subseries, with a mean elevation of $1,293 \mathrm{ft}$, and the Mixed Oak-Coast Live Oak/Poison Oak type, with a mean elevation of $1,465 \mathrm{ft}$, are significantly lower in elevation than all Sierran types except the Black Oak/Poison Oak-California Storax/Grass-nut type. The Coast Range types, Black Oak-Coast Live Oak-Beach Pine/Ocean Spray and Black Oak-Valley Oak/Grass, occur at $1,691 \mathrm{ft}$ and $2,375 \mathrm{ft}$, respectively.

The four types found in both the Coast and Sierra Nevada Ranges are generally middle elevation types within the Black Oak Series (table 3). The Black Oak/Poison Oak type occurs at a mean elevation of $2,486 \mathrm{ft}$, the Black Oak/Poison Oak/Grass type at 2,746 ft, the Black Oak-Canyon Live Oak/Poison Oak type at 2,963 ft, and the Canyon Live Oak-Black Oak type at 3,231 ft, all significantly higher than all strictly Coast Range types except for the Black Oak-Valley Oak/Grass type.

The four types found strictly in the Sierra Nevada have a wide range of mean elevation. The Black Oak/Poison Oak-California Storax/Grass-nut type averages $1,484 \mathrm{ft}$, significantly lower than all other Sierra types. Mid-elevation types include Black Oak/Deerbrush-Poison Oak/Bracken Fern at 2,527 ft mean elevation and Black Oak/Deerbrush at 3,435 ft. The highest subseries is Black Oak/Greenleaf Manzanita, significantly higher than all other black oak subseries at 5,647 ft mean elevation. The Black Oak/Grass subseries, which occurs in both the Transverse and Coast ranges, is also a high elevation type (table 3).

Mean basal area of black oak for the four Coast Range subseries ranges from $38 \mathrm{ft}^{2} /$ acre in the Mixed Oak-Coast Live Oak/Poison Oak type to $53 \mathrm{ft}^{2} /$ acre in the Black Oak-Coast Live Oak-Beach Pine/Ocean Spray type, with no significant differences (fig. 5). The Black Oak-Madrone-Coast Live Oak type is distinguished from its coastal associates by the presence of significantly more basal area of madrone and significantly less coast live oak. The Black Oak-Valley Oak/Grass type contains valley oak with a mean basal area of $32 \mathrm{ft}^{2} /$ acre, significantly more than any other black oak type. The Mixed Oak-Coast Live Oak/Poison Oak type is distinguished from the Black Oak-Coast Live Oak-Beach Pine/Ocean Spray type by the absence of ocean spray and beach pine, and significantly less grass than the Black Oak-Valley Oak/Grass type.

Five subseries occur in both the Coast and Sierra Nevada Ranges, and Coast and Transverse Ranges (table 3). Mean basal area of black oak is $115 \mathrm{ft}^{2} /$ acre for the Black Oak/Poison Oak type significantly higher than any other black oak subseries (fig. 5). The Black Oak/Poison Oak type can be further distinguished from the Black Oak/Poison Oak/Grass subseries by the absence of grass. The Black Oak-Canyon Live Oak/Poison Oak type and the Canyon Live Oak-Black Oak type can be distinguished from other black oak subseries by the presence of canyon live oak as a codominant species. The Black Oak-Canyon Live Oak/Poison Oak type has a significantly higher mean basal area of black oak and significantly less cover of understory canyon live oak than the Canyon Live Oak-Black Oak type. 


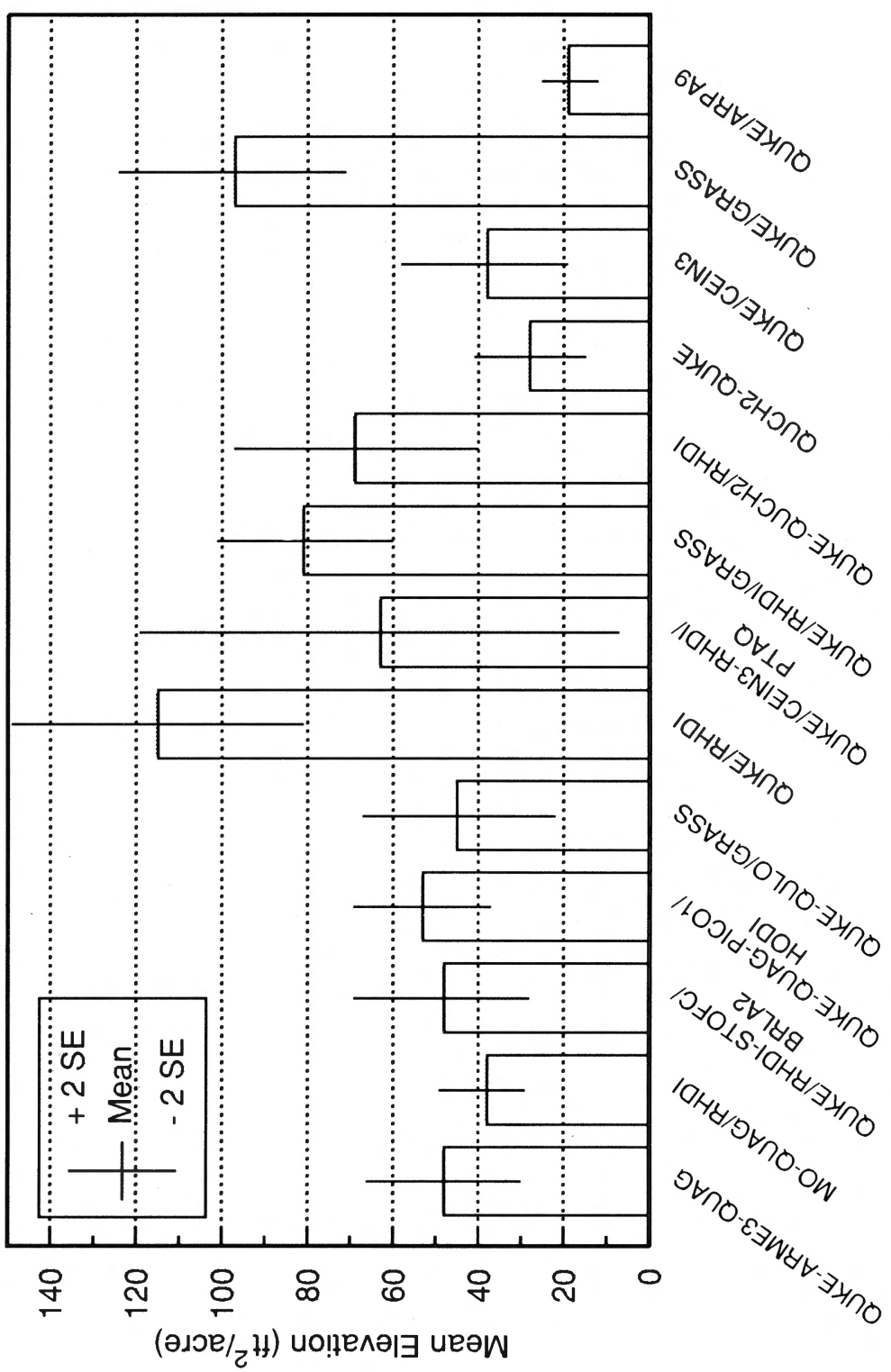

Fig. 5. Comparison of mean black oak basal area by black oak subseries. Bars represent the 95 percent confidence interval around the mean, approximately \pm 2 standard errors. Note wide range of productivity among types. 
The Black Oak/Grass type is found in both the Coast Range and the Transverse Range. Black oak mean basal area is $97 \mathrm{ft}^{2} /$ acre, significantly higher than all types occurring strictly in the Coast Range (fig. 5).

In the Sierra Nevada types, black oak mean basal area ranges from $19 \mathrm{ft}^{2} /$ acre for the Black Oak/Greenleaf Manzanita type to $63 \mathrm{ft}^{2} /$ acre for the Black Oak/DeerbrushPoison Oak/Bracken Fern type, with only these two types being significantly different from each other. The Black Oak/Poison Oak-California Storax/Grass-nut type has significantly more cover of poison oak than all other black oak types. The Black Oak/Deerbrush-Poison Oak/Bracken Fern type and the Black Oak/Deerbrush types are distinguished from each other by significantly higher mean cover of deerbrush in the latter, and the presence of bracken fern in the former.

\section{THE CALIFORNIA SCRUB OAK SERIES}

The Scrub Oak Series is comprised of cover types that have scrub oak as a dominant or codominant species in the overstory (fig. 6). This series is comprised of three subseries, all found at a mean elevation of about $1,400 \mathrm{ft}$ on northerly facing slopes in the central coastal ranges, in San Benito, Monterey, and San Luis Obispo Counties. Parent material of the soils of these sites is mostly shale, with some sandstone.

The Scrub Oak-Blue Oak/Grass subseries has both scrub oak and blue oak in the overstory, which distinguishes this type from the other two types that have no blue oak. Scrub oak and blue oak are usually codominant; mean basal area of scrub oak is 34 $\mathrm{ft}^{2} /$ acre, compared with $21 \mathrm{ft}^{2} /$ acre for blue oak. Scrub oak occurs in the understory with $64 \%$ constancy, but averages only $5 \%$ cover. Grass averages $85 \%$ cover with $100 \%$ constancy. This type is more likely to be found on clay loam soils than the other types.

The Scrub Oak/Grass subseries has scrub oak as the only dominant overstory species, averaging $50 \mathrm{ft}^{2} /$ acre of basal area. Scrub oak is usually present in the understory as well, averaging $9 \%$ with $87 \%$ constancy. Grass is the only other major component of the understory, averaging $78 \%$ with $100 \%$ constancy.

The Scrub Oak subseries has scrub oak as the only major species present. Mean basal area of scrub oak ( $73 \mathrm{ft}^{2} /$ acre) is significantly higher in this type than in the Scrub Oak-Blue Oak/Grass type (fig. 6). Understory scrub oak cover, averaging $21 \%$ with $91 \%$ constancy, is also significantly higher in this type than in the Scrub Oak-Blue Oak/Grass type. Grass occurs with only a $45 \%$ constancy, and averages $10 \%$ cover, significantly less than the other two types. Litter is common, with $91 \%$ constancy and $60 \%$ mean cover, while it is rare in the other types. Toyon and/or hollyleaf cherry can be found more than one-third of the time in the understory. Most of the soils for this type have a gravelly or rocky component.

\section{THE CALIFORNIA MIXED OAK SERIES}

The Mixed Oak series is comprised of cover types that contain three or more species of Quercus with constancies of $30 \%$ or more. This series is comprised of 11 subseries; nine types are found in the Coast Ranges and two types are found in the Sierra Nevada (table 3). 


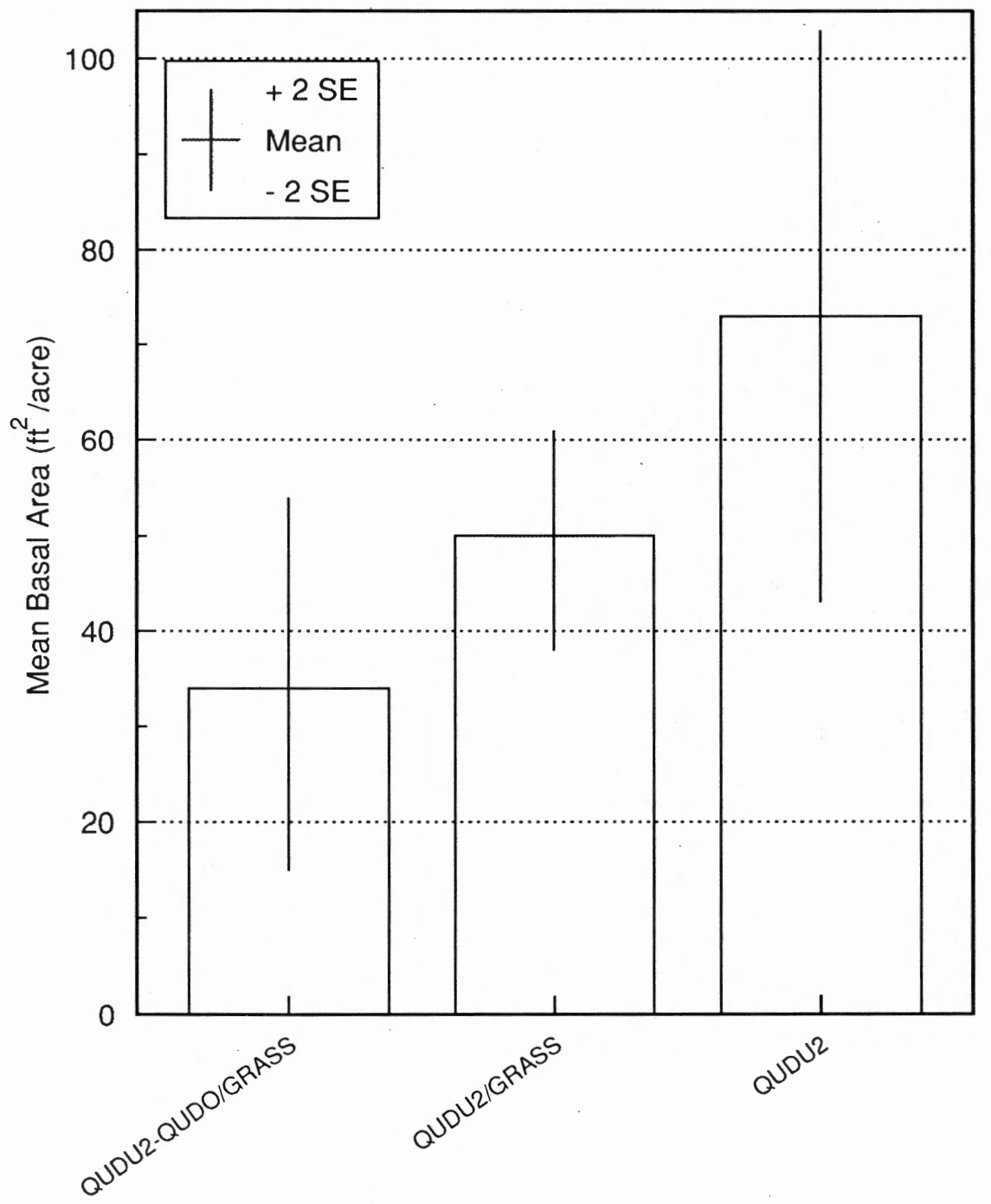

Fig. 6. Comparison of scrub oak mean basal area by type. Bars represent the 95 percent confidence interval around the mean, approximately \pm 2 standard errors. The QUDU2-QUDO/GRASS subseries also contains blue oak with a mean of $21 \mathrm{ft}^{2} /$ acre. 
The two Sierra Nevada types, Mixed Oak-Interior Live Oak-Foothill Pine and Interior Live Oak/Toyon, exist at similar elevations (1,900 ft) from Placer County in the northern Sierra to Madera County in the south. Both types are dominated by interior live oak (fig. 7), but also contain black oak and blue oak. The Mixed Oak-Interior Live Oak-Foothill Pine type has a significantly higher mean basal area of foothill pine and blue oak, and no understory interior live oak. Overall mean basal area is higher for this type. In addition, this type contains significantly more grass cover, averaging $78 \%$, compared to an average of $42 \%$ grass cover for the Interior Live Oak/Toyon type.

There are three Coast Range lower elevation mixed oak subseries (fig. 8). The Mixed Oak-California Buckeye/Grass type tends to occur on the driest sites of the three lower elevation subseries at an average of $872 \mathrm{ft}$ elevation. The Mixed Oak/Grass type occurs in the middle of the moisture gradient at an average of $1,019 \mathrm{ft}$ elevation, while the Mixed Oak/Poison Oak-Baccharis type tends to occur on the moister end at an average of $950 \mathrm{ft}$. The Mixed Oak-California Buckeye/Grass type is generally found in the central coast from Napa to San Benito Counties. Compared to its other two lower elevation mixed oak associates, this type tends to be found on the central valley side of the Coast Ranges on sandy and gravelly loams. The Mixed Oak/Grass and Mixed Oak/Poison Oak-Baccharis types tend to have a wider geographic range, occurring from Napa to Santa Barbara Counties.

The Mixed Oak/Poison Oak-Baccharis subseries has less mean basal area of blue oak and more valley oak than its other two coastal low-elevation associates. It also has significantly more cover of coffeeberry than the other two subseries. The Mixed OakCalifornia Buckeye/Grass type is distinguished from its low-elevation associates by its high constancy (though low overall mean basal area) of California buckeye. The Mixed Oak-California Buckeye/Grass type also has significantly more grass cover (97\%) than its associates; the Mixed Oak/Grass type also has a higher mean grass cover (64\%) than the Mixed Oak/Poison Oak-Baccharis type (24\%).

The Coast Range middle elevation subseries include the Mixed Oak-Foothill Pine/Grass, Mixed Oak-Valley Oak/Poison Oak-Coffeeberry, Mixed Oak-Coast Live Oak/Poison Oak, and Mixed Oak-Black Oak/Grass types (fig. 9). Each subseries is named for the dominant oak species in oak species mixture. The Mixed Oak-Foothill Pine/Grass type tends to be the driest of the four middle elevation types. It occurs primarily in the Coast Ranges from Contra Costa to Santa Barbara and Kern Counties, at a mean elevation of $1,526 \mathrm{ft}$. Slopes are commonly less than $35 \%$ and this type is located primarily on sandstone and shale parent materials on northwest to east aspects.

The Mixed Oak-Valley Oak/Poison Oak-Coffeeberry type is distinguished from its middle-elevation associates by its significantly higher mean basal areas of valley oak ( 84 $\mathrm{ft}^{2} /$ acre) and coast live oak ( $108 \mathrm{ft}^{2} /$ acre $)$. Valley oak is present $100 \%$ of the time, and coast live oak has a constancy of $99 \%$ in this type. There is also a noticeable absence of black oak in this subseries. The type may be found from Marin and Contra Costa Counties to San Luis Obispo County at mean elevations of 1,443 ft. The Mixed Oak-Valley Oak/Poison Oak-Coffeeberry subseries is found on a wide range of slopes (flat to very steep), and aspects (including $40 \%$ on south to west aspects). Parent material is primarily shale, but this type is also found on granitics, serpentine, and sandstones, among others.

The Mixed Oak-Coast Live Oak/Poison Oak type is distinguished from the Mixed Oak-Black Oak/Grass type by the absence of blue oak in the type, and its significantly 


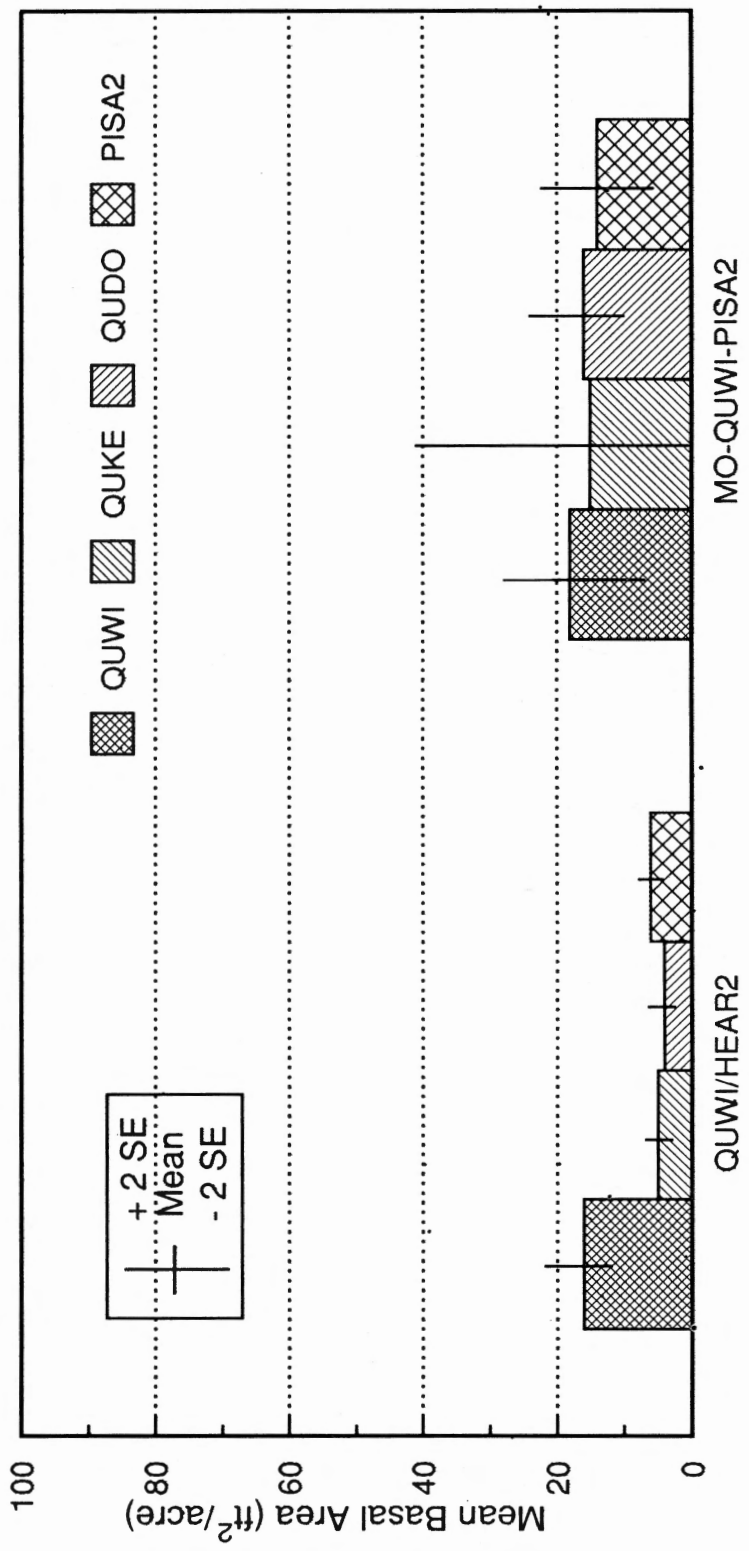

Fig. 7. Comparison of mean basal area of major tree species contained within the mixed oak subseries found in the Sierra Nevada. Bars represent the 95 percent confidence interval around the mean, approximately \pm 2 standard errors. Note foothill pine and interior live oak are not major species in the other oak types (figs. 8-10). 


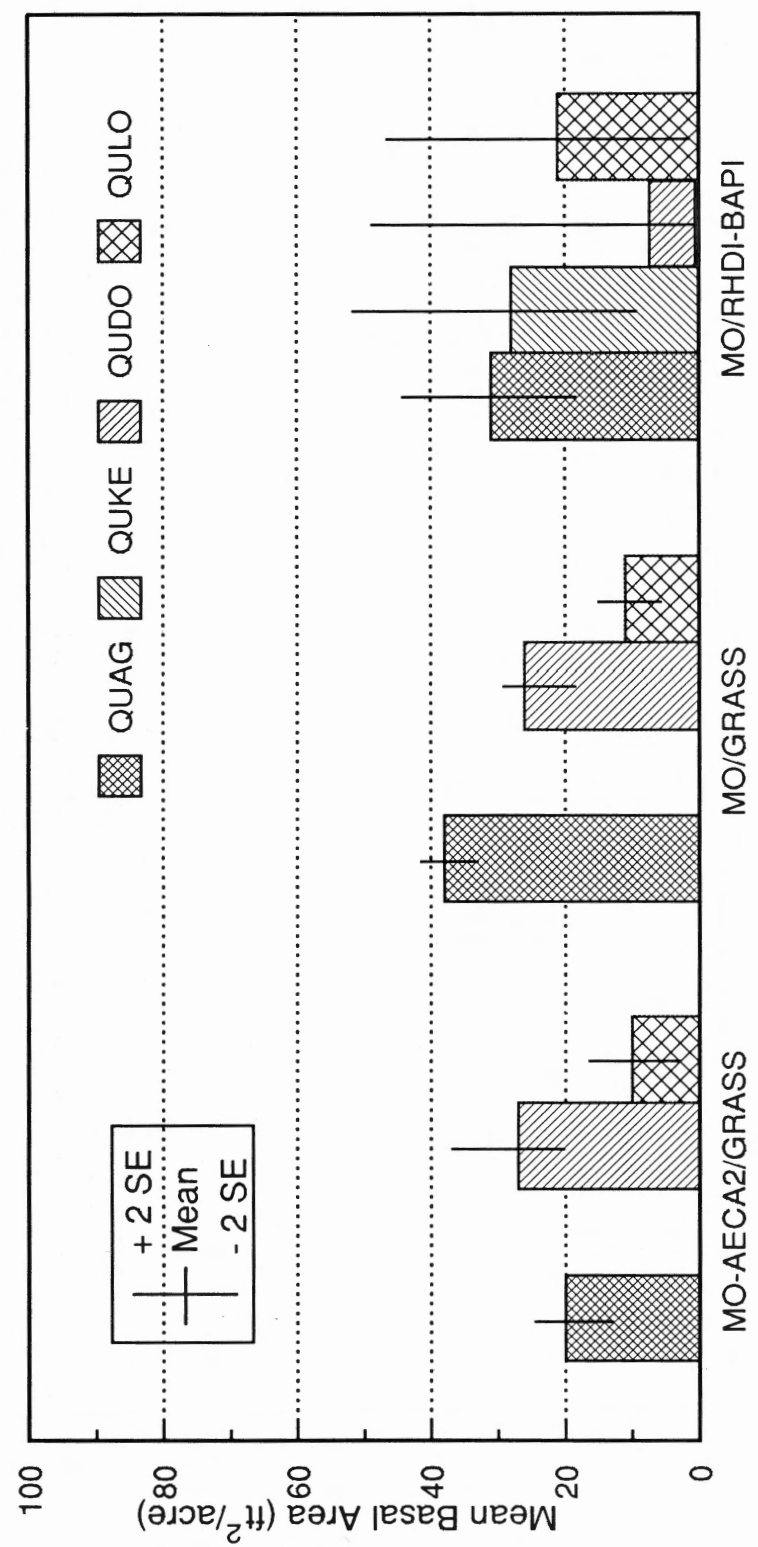

Fig. 8. Comparison of major tree species' mean basal area for mixed oak subseries found in the Coast Ranges at low elevations. Bars represent the 95 percent confidence interval around the mean, approximately \pm 2 standard errors. 


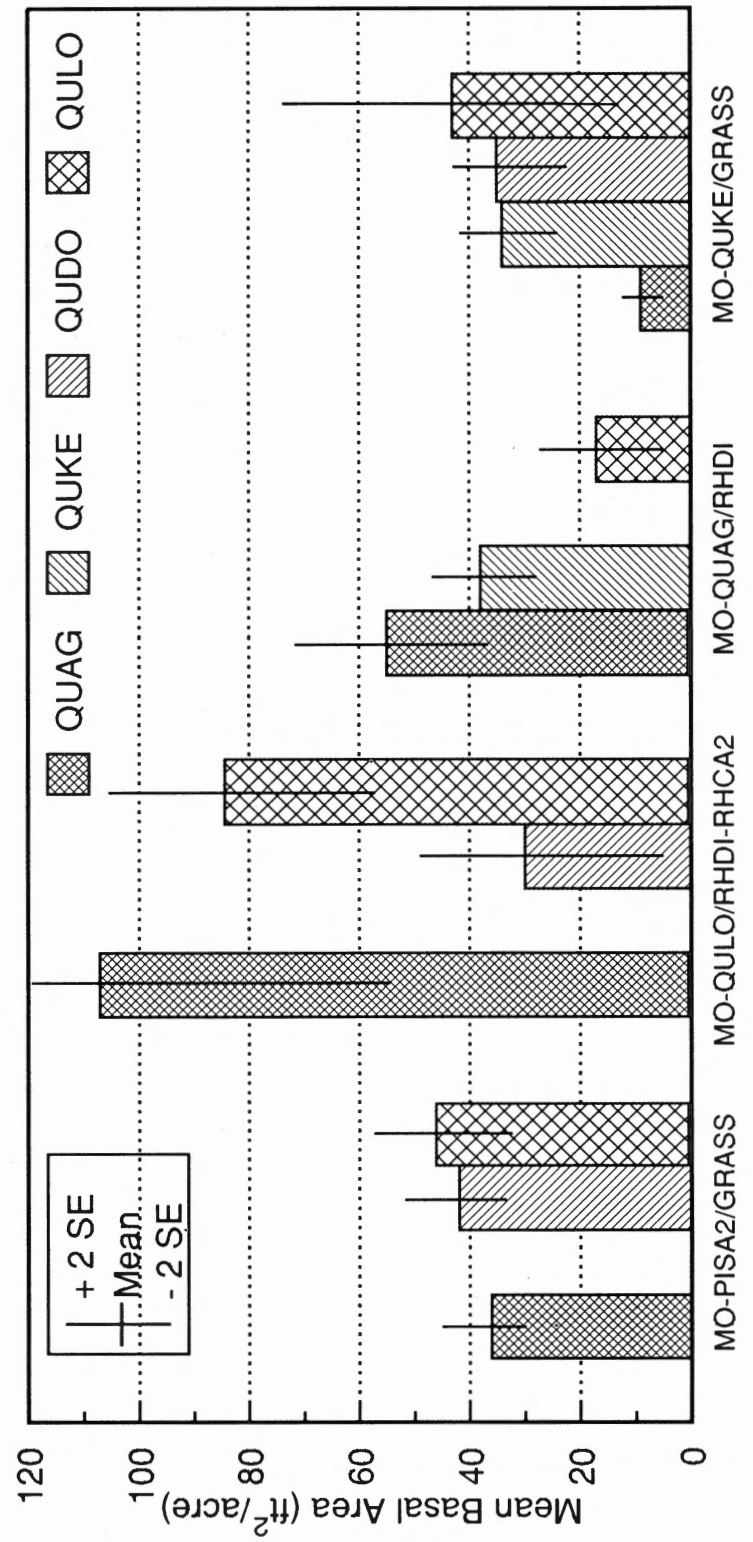

Fig. 9. Comparison of mean basal area of major tree species for coastal middle elevation mixed oak subseries. Bars represent the 95 percent confidence interval around the mean, approximately \pm 2 standard errors. 
higher mean basal area of coast live oak (fig. 9). Additionally, the Mixed Oak-Coast Live Oak/Poison Oak type has significantly less grass cover than the Mixed Oak-Black Oak/Grass type.

The Mixed Oak-Coast Live Oak/Poison Oak type tends to occur on steeper slopes than its other middle-elevation associates, and occurs on all soil textures and a wide range of parent materials from Sonoma to Monterey Counties. The Mixed Oak-Black Oak/Grass subseries occurs primarily on soft sedimentary sandstone parent material, although it also may occur on shales, metamorphic, and other parent materials. Although primarily a coast range type, $10 \%$ of the samples representing the Mixed Oak-Black Oak/Grass subseries are found in the Sierra Nevada.

The Blue Oak-Valley Oak-Coast Live Oak/Grass subseries occurs at a mean elevation of $1,567 \mathrm{ft}$ (fig. 10). It is distinguished from its ather coastal middle and upperelevation associates by the lack of black oak and foothill pine, and the high constancy and cover of grass as the only understory species.

The Blac: Oak-Valley Oak/Grass subseries is distinguished from all its other coastal associates by elevation. It is the highest of the Mixed Oak Series types with a mean elevation of 2,375 ft. Black oak and grass are always present in the type, with very few other species in the understory. Coast live oak is a common associate occurring on $47 \%$ of the plots representing this type.

\section{DISCUSSION}

The hardwood rangeland classification system for California provides private landowners, land managers, and researchers a unifying framework from which known ecological and management information can be retrieved. Standardization of type names facilitates the exchange of information on hardwood rangelands within and among agencies, landowners, and universities. The dichotomous keys to the type descriptions ensure that the system is easily accessible, field oriented, and user-friendly.

The classification system is more detailed than any existing hardwood rangeland classification system. Unlike other systems, this classification incorporates environmental information, in addition to floristics, in distinguishing types. This results in a natural classification system useful for a number of management and research purposes (Allen 1987; Pfister and Arno 1980).

Land managers can use the classification framework for labelling management units, thus facilitating communication between functional specialists. For example, a wildlife biologist may label a site using the wildlife habitats classification system (Mayer and Laudenslayer 1988), which is general in nature. A forester may look at the same piece of ground and label the site using the Society of American Forester forest cover type designation (Eyre 1980) based on dominant (often commercial) tree species. On the other hand, the range conservationist may label the site using range sites (Soil Conservation Service 1986) based on the potential to graze livestock or. some other more general system. The hardwood rangeland cover type system provides a common labelling system for all these specialists, is specific in nature, and is not tied to any particular use. Additionally, the system provides crosswalks to other classifications so that the user can access information from these systems. 


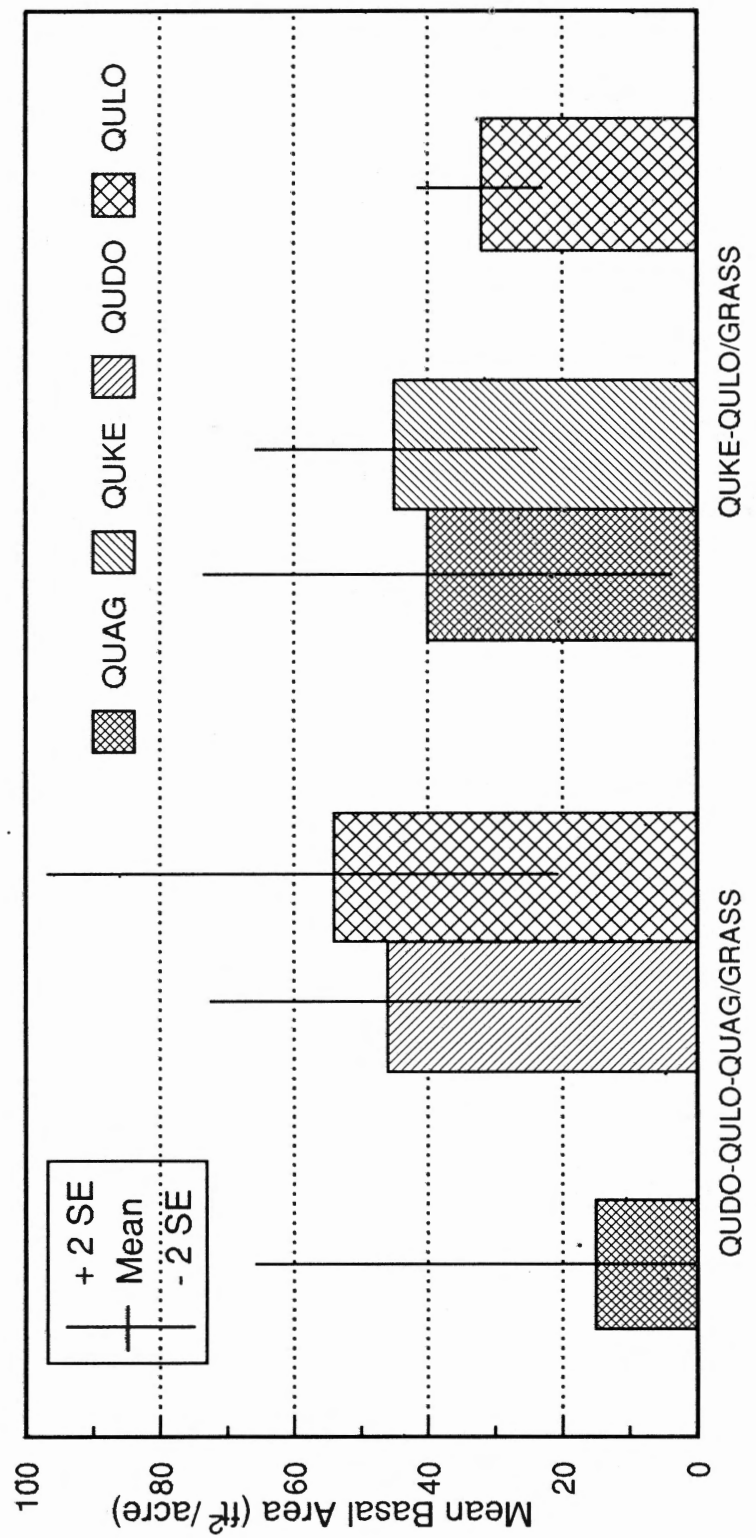

Fig. 10. Comparison of mean basal area of major tree species for coastal upper elevation mixed oak subseries. Bars represent the 95 percent confidence interval around the mean, approximately \pm 2 standard errors. 
Researchers can use the hardwood rangeland cover type classification for labelling research sites and thus facilitate the transfer of information. Information on production of trees, shrubs, and herbaceous species can be stored and retrieved by type. Similarly, research information on wildlife habitat, suitability for grazing or harvesting, or other kinds of research results can be accessed if researchers identify their research sites using these common labels. As more information is collected, the successional relationships between types can be identified, making the hardwood rangeland cover type system a stronger, integrated, hierarchical system.

The hardwood rangeland classification system was developed from attributes of vegetation and environment that were contained within an existing data set (the VTM data set). Thus, the classification system is constrained by the data elements available. One of the most obvious weaknesses in the data set is the lack of soils information and the incomplete list of grass and other graminoid species. Even so, field checking and discussion with oak woodland experts indicate that the classification should apply to at least $80 \%$ of the possible oak woodland subseries cover types comprising the Series presented here. This applicability is comparable to detailed ecological site classification systems based on complete species lists and detailed soils information.

New types will be added to the hardwood rangeland system as appropriate, as documented by field work and additional analysis. Existing types will be refined, as appropriate, as users make suggestions. Information on tree and understory productivity, wildlife habitat, and potential responses to management treatments for existing types will be added as information becomes available from the literature and research. Meanwhile, the classification system will provide common labels, and a storage and retrieval system for researchers and managers alike. 
APPENDIX 1: PLANT SPECIES CODES WITH SCIENTIFIC NAMES AND COMMON NAMES

FROM MUNZ AND KECK (1968) AND POWELL (1987)

\begin{tabular}{|c|c|c|c|c|}
\hline VEGCODE & GENUS & SPECIES & VARIETY & COMMON NAME \\
\hline $\mathrm{ABCO}$ & ABIES & CONCOLOR & $-0-$ & White fir \\
\hline ACMA & ACER & MACROPHYLLUM & $-0-$ & Bigleaf maple \\
\hline ADFA & ADENOSTOMA & FASCICULATUM & $-0-$ & Chamise \\
\hline AECA-2 & AESCULUS & CALIFORNICA & $-0-$ & California buckeye \\
\hline AMCA-2 & AMORPHA & CALIFORNICA & $-0-$ & Mock locust \\
\hline AMUT & AMELANCHIER & UTAHENSIS & $-0-$ & Utah serviceberry \\
\hline APCA & APOCYNUM & CANNABINUM & $-0-$ & Indian hemp \\
\hline ARCA-5 & ARCTOSTAPHYLOS & CANESCENS & $-0-$ & Hoary manzanita \\
\hline ARCA-7 & ARTEMISIA & CALIFORNICA & $-0-$ & Coast sagebrush \\
\hline ARCO-6 & ARCTOSTAPHYLOS & COLUMBIANA & $-0-$ & Hairy manzanita \\
\hline ARGL-5 & ARCTOSTAPHYLOS & GLAUCA & $-0-$ & Bigberry manzanita \\
\hline ARMA-3 & ARCTOSTAPHYLOS & MANZANITA & $-0-$ & Common manzanita \\
\hline ARMA-4 & ARCTOSTAPHYLOS & MARIPOSA & $-0-$ & Mariposa manzanita \\
\hline ARME-2 & ARCTOSTAPHYLOS & MEWUKKA & $-0-$ & Indian manzanita \\
\hline ARME-3 & ARBUTUS & MENZIESII & $-0-$ & Madrone \\
\hline AROB-2 & ARCTOSTAPHYLOS & OBISPOENSIS & $-0-$ & Serpentine manzanita \\
\hline ARPA-9 & ARCTOSTAPHYLOS & PATULA & $-0-$ & Greenleaf manzanita \\
\hline ARPRD & ARCTOSTAPHYLOS & PRINGLEI & drupa & Pink-bracted manzanita \\
\hline ARPU-6 & ARCTOSTAPHYLOS & PUNGENS & $-0-$ & Mexican manzanita \\
\hline ARTO-2 & ARCTOSTAPHYLOS & TOMENTOSA & $-0-$ & Shaggy barked manzanita \\
\hline ARTR & ARTEMISIA & TRIDENTATA & $-0-$ & Basin sagebrush \\
\hline ARVI-3 & ARCTOSTAPHYLOS & VISCIDA & $-0-$ & Whiteleaf manzanita \\
\hline BAPI & BACCHARIS & PILULARIS & -0 & Baccharis \\
\hline BRLA-2 & BRODIAEA & LAXA & $-0-$ & Grass-nut \\
\hline CASE-3 & CASTANOPSIS & SEMPERVIRENS & $-0-$ & Bush chinquapin \\
\hline CEBE-2 & CERCOCARPUS & BETULOIDES & $-0-$ & Birchleaf mountain-mahogany \\
\hline CECO-2 & CEANOTHUS & CORDULATUS & $-0-$ & Mountain whitethorn \\
\hline CECU-2 & CEANOTHUS & CUNEATUS & $-0-$ & Wedgeleaf ceanothus \\
\hline CEIN-3 & CEANOTHUS & INTEGERRIMUS & $-0-$ & Deerbrush \\
\hline CELE-2 & CEANOTHUS & LEUCODERMIS & $-0-$ & Chaparral whitethorn \\
\hline CEOC & CERCIS & OCCIDENTALIS & $-0-$ & California redbud \\
\hline
\end{tabular}




\begin{tabular}{|c|c|c|c|c|}
\hline VEGCODE & GENUS & SPECIES & VARIETY & COMMON NAME \\
\hline CEPA-3 & CEANOTHUS & PAPILLOSUS & -0 & Warty-leaved ceanothus \\
\hline CEPA-5 & CEANOTHUS & PARVIFOLIUS & -0 & Littleleaf ceanothus \\
\hline CEPR & CEANOTHUS & PROSTRATUS & -0 & Squaw carpet \\
\hline CESO-3 & CEANOTHUS & SOREDIATUS & $-0-$ & Jim brush \\
\hline CESP & CEANOTHUS & SPINOSUS & $-0-$ & Greenbark ceanothus \\
\hline CETH & CEANO'THUS & THYRSIFLORUS & -0 & Blueblossom ceanothus \\
\hline CETO & CEANOTHUS & TOMENTOSUS & $-0-$ & Woollyleaf ceanothus \\
\hline $\mathrm{CHFO}-2$ & CHAMAEBATIA & FOLIOLOSA & -0 & Mountain misery \\
\hline COCA-8 & CORETHROGYNE & CALIFORNICA & $-0-$ & $-0-$ \\
\hline $\mathrm{COCO}-5$ & CORỴLUS & CORNUTA & -0 & Hazelnut \\
\hline CONU-2 & CORNUS & NUTTALLII & -0 & Pacific dogwood \\
\hline COROC & CORYLUS & ROSTRATA & calif & -0 \\
\hline CRCA-2 & CRO'TON & CALIFORNICUS & -0 & California croton \\
\hline DERI & DENDROMECON & RIGIDA & -0 & Tree poppy \\
\hline DIAU-1 & DIPLACUS & AURANTIACUS & $-0-$ & Bush monkeyflower \\
\hline ERCA-6 & ERIODICTYON & CALIFORNICUM & -0 & California yerba santa \\
\hline ERCI-2 & ERODIUM & CICUTARIUM & $-0-$ & Red-stem filaree \\
\hline ERCO-7 & ERIOPHYLLUM & CONFERTIFLORUM & -0 & Yellow yarrow \\
\hline ERCR-2 & ERIODICTYON & CRASSIFOLIUM & -0 & Thick-leaf yerba santa \\
\hline ERFA & ERIOGONUM & FASCICULATUM & -0 & California buckwheat \\
\hline ERPA-3 & ERIOGONUM & PARVIFOLIUM & $-0-$ & Dune eriogonum \\
\hline ERWR & ERIOGONUM & WRIGHTII & -0 & Buckwheat \\
\hline FRCA-2 & FREMONTIA & CALIFORNICA & $-0-$ & Flannel bush \\
\hline FRDI & FRAXINUS & DIPETALA & $-0-$ & Foothill ash \\
\hline GAEL & GARRYA & ELLIPTICA & -0 & Coast silktassel \\
\hline GAFLP & GARRYA & FLAVESCENS & palli & Ashy silktassel \\
\hline GAFR & GARRYA & FREMONTII & -0 & Fremont silktassel \\
\hline GAVE-2 & GARRYA & VEATCHII & -0 & Veatch silktassel \\
\hline GR2 & & & & Grass \\
\hline HAAR & HAPLOPAPPUS & ARBORESCENS & $-0-$ & Goldenfleece \\
\hline HALI & HAPLOPAPPUS & LINEARIFOLIUS & $-0-$ & Narrowleaf goldenbush \\
\hline HASQ-2 & HAZARDIA & SQUARROSA & -0 & Sawtooth goldenbush \\
\hline
\end{tabular}


APPENDIX 1 (Continued)

\begin{tabular}{|c|c|c|c|c|}
\hline VEGCODE & GENUS & SPECIES & VARIETY & COMMON NAME \\
\hline HEAR-2 & HETEROMELES & ARBUTIFOLIA & -0 & Toyon, christmas berry \\
\hline HODI & HOLODISCUS & DISCOLOR & -0 & Ocean spray, Creambush \\
\hline HYPE & HYPERICUM & PERFORATUM & $-0-$ & Klamath weed \\
\hline JUCA-3 & JUNIPERUS & CALIFORNICA & -0 & California juniper \\
\hline JUCA-4 & JUGLANS & CALIFORNICA & -0 & Southern black walnut \\
\hline LECA-3 & LEPECHINIA & CALYCINA & $-0-$ & Woodbalm \\
\hline LIDE-2 & LITHOCARPUS & DENSIFLORUS & -0 & Tan-oak \\
\hline LOIN-3 & LONICERA & INTERRUPTA & $-0-$ & Chaparral honeysuckle \\
\hline LOSC & LOTUS & SCOPARIUS & -0 & Lotus \\
\hline LOSU-3 & LONICERA & SUBSPICATA & $-0-$ & Southern honeysuckle \\
\hline LUAL-3 & LUPINUS & ALBIFRONS & -0 & Silver lupine \\
\hline LUP-5 & LUPINUS & SP. WOODY SHRUB & -0 & Bush lupine \\
\hline $\mathrm{MECH}$ & MESEMBRYANTHEMUM & CHILENSE & -0 & Iceplant \\
\hline MYCA & MYRICA & CALIFORNICA & -0 & Pacific wax-myrtle \\
\hline PECO-3 & PENSTEMON & CORDIFOLIUS & $-0-$ & -0 \\
\hline PHLEC & PHILADELPHUS & LEWISII & californicus & California mock orange \\
\hline PIAT-1 & PINUS & ATTENUATA & $-0-$ & Knobcone pine \\
\hline PICO-1 & PINUS & CONTORTA & -0 & Beach (lodgepole) pine \\
\hline PICO-2 & PINUS & COULTERI & $-0-$ & Coulter pine \\
\hline PIJE & PINUS & JEFFREYI & -0 & Jeffrey pine \\
\hline PILA & PINUS & LAMBERTIANA & -0 & Sugar pine \\
\hline PIMO-2 & PINUS & MONOPHYLLA & -0 & One-needle pinyon pine \\
\hline PIMU-1 & PINUS & MURICATA & -0 & Bishop pine \\
\hline PIPO & PINUS & PONDEROSA & -0 & Ponderosa pine \\
\hline PIQU & PINUS & QUADRIFOLIA & -0 & Four-needle pinyon pine \\
\hline PIRA & PINUS & RADIATA & -0 & Monterey pine \\
\hline PISA-2 & PINUS & SABINIANA & -0 & Foothill pine \\
\hline PLRA & PLATANUS & RACEMOSA & -0 & Western sycamore \\
\hline POMU-1 & POLYSTICHUM & MUNITUM & -0 & Sword fern \\
\hline PREM & PRUNUS & EMARGINATA & -0 & Bitter cherry \\
\hline
\end{tabular}




\begin{tabular}{|c|c|c|c|c|}
\hline VEGCODE & GENUS & SPECIES & VARIETY & COMMON NAME \\
\hline PRIL-1 & PRUNUS & ILICIFOLIA & $-0-$ & Shrub hollyleaf cherry \\
\hline PRSU-2 & PRUNUS & SUBCORDATA & -0 & Sierra plum \\
\hline PRVID & PRUNUS & VIRGINIANA & demissa & Western choke-cherry \\
\hline PSMA-2 & PSEUDOTSUGA & MACROCARPA & $-0-$ & Big-cone spruce \\
\hline PSME & PSEUDOTSUGA & MENZIESII & $-0-$ & Douglas-fir \\
\hline PSPH & PSORALEA & PHYSODES & $-0-$ & California tea \\
\hline PTAQL & PTERIDIUM & AQUILINUM & lanuginosum & Bracken fern \\
\hline PTAQP & PTERIDIUM & AQUILINUM & pubescens & Bracken fern \\
\hline QUAG & QUERCUS & AGRIFOLIA & $-0-$ & Coast live oak \\
\hline QUCH-2 & QUERCUS & CHRYSOLEPIS & $-0-$ & Canyon live oak \\
\hline QUDO & QUERCUS & DOUGLASII & $-0-$ & Blue oak \\
\hline QUDU-2 & QUERCUS & DUMOSA & $-0-$ & California scrub oak \\
\hline QUEN-1 & QUERCUS & ENGELMANNII & -0 & Engelmann oak \\
\hline QUGA-2 & QUERCUS & GARRYANA & -0 & Oregon oak, garry oak \\
\hline QUGAB & QUERCUS & GARRYANA & breweri & Brewer oak \\
\hline QUKE & QUERCUS & KELLOGGII & $-0-$ & California black oak \\
\hline QULO & QUERCUS & LOBATA & $-0-$ & Valley oak \\
\hline QUMO & QUERCUS & MOREHUS & x quwiw \& qukek & Oracle oak \\
\hline QUVA & QUERCUS & VACCINIFOLIA & $-0-$ & Huckleberry oak \\
\hline QUWI & QUERCUS & WISLIZENII & $-0-$ & Interior live oak \\
\hline RHCA-2 & RHAMNUS & CALIFORNICA & -0 & California coffeeberry \\
\hline RHCR & RHAMNUS & CROCEA & $-0-$ & Redberry \\
\hline RHDI & RHUS & DIVERSILOBA & $-0-$ & Poison-oak \\
\hline RHLA & RHUS & LAURINA & $-0-$ & Laurel sumac \\
\hline RHRU & RHAMNUS & RUBRA & -0 & Sierra coffeeberry \\
\hline RHTR & RHUS & TRILOBATA & $-0-$ & Squaw bush \\
\hline RIAU & RIBES & AUREUM & $-0-$ & Golden currant \\
\hline RIB & RIBES & SP. WOODY SHRUB & $-0-$ & Gooseberry, currant \\
\hline RICA-1 & RIBES & CALIFORNICUM & -0 & Hillside gooseberry \\
\hline RIMA-1 & RIBES & MALVACEUM & $-0-$ & Chaparral currant \\
\hline RIQU & RIBES & QUERCETORUM & $-0-$ & Foothill gooseberry \\
\hline RIRO & RIBES & ROEZLII & -0 & Sierra gooseberry \\
\hline
\end{tabular}


APPENDIX 1 (Continued)

\begin{tabular}{|c|c|c|c|c|}
\hline VEGCODE & GENUS & SPECIES & VARIETY & COMMON NAME \\
\hline RISA & RIBES & SANGUINEUM & $-0-$ & Red flowering currant \\
\hline RISP & RIBES & SPECIOSUM & $-0-$ & Fuchsia-flower gooseberry \\
\hline ROCA-1 & ROSA & CALIFORNICA & $-0-$ & California wild rose \\
\hline ROGY & ROSA & GYMNOCARPA & $-0-$ & Wood rose \\
\hline ROS & ROSA & SP. WOODY SHRUB & -0 & Rose \\
\hline RUPA-2 & RUBUS & PARVIFLORUS & $-0-$ & Western thimbleberry \\
\hline RUVI-1 & RUMEX & VIOLASCENS & $-0-$ & $-0-$ \\
\hline RUVI-2 & RUBUS & SP. SHRUB & $-0-$ & Blackberry \\
\hline SAAP-1 & SALVIA & APIANA & $-0-$ & White sage \\
\hline SACA-4 & SAMBUCUS & CAERULEA & -0 & Mountain blue elderberry \\
\hline SAL-11 & SALIX & SP. WOODY SHRUB & $-0-$ & Willow \\
\hline SALE-2 & SALVIA & LEUCOPHYLLA & $-0-$ & Purple sage \\
\hline SAME-4. & SALVIA & MELLIFERA & $-0-$ & Black sage \\
\hline SAME-6 & SAMBUCUS & MEXICANA & $-0-$ & Blue elderberry \\
\hline SASP & SALVIA & SPATHACEA & $-0-$ & Pitcher sage \\
\hline SESE-2 & SEQUOIA & SEMPERVIRENS & $-0-$ & Coast redwood \\
\hline STOFC & STYRAX & OFFICINALIS & californica & California storax \\
\hline SYMO & SYMPHORICARPOS & MOLLIS & $-0-$ & Creeping snowberry \\
\hline SYRI & SYMPHORICARPOS & RIVULARIS & $-0-$ & Upright snowberry \\
\hline UMCA-1 & UMBELLULARIA & CALIFORNICA & $-0-$ & California laurel, bay tree \\
\hline VAOV & VACCINIUM & OVATUM & $-0-$ & California huckleberry \\
\hline XYBI & XYLOCOCCUS & BICOLOR & -0 & Mission manzanita \\
\hline YUWH & YUCCA & WHIPPLEI & -0 & Chaparral yucca \\
\hline
\end{tabular}




\section{LITERATURE CITED}

ALLEN, B. H.

1987. Ecological type classification for California: The Forest Service Approach. Gen. Tech. Rep. PSW-98. Berkeley, CA: USDA Forest Service, Pacific Southwest Forest and Range Exp. Sta.

BARBOUR, M, G. and J. MAJOR

1988. Terrestrial Vegetation of California. 2d ed. Sacramento, CA: Calif. Native Plant Soc. BOLSINGER, C. L.

1988. The hardwoods of California's timberlands, woodlands, and savannas. Resour. Bull. PNW-RB-148. USDA Forest Service, Pacific Northwest Res. Sta.

CAMPBELL, $\mathrm{B}$.

1980. Some mixed hardwood forest communities of the coastal ranges of southern California. Phytocoenologia 8:279-320.

CHEATHAM, N. H. and J. R. HALLER

1975. An annotated list of California habitat types. Berkeley: Univ. Calif. Nat. Land and Water Reser. Sys. Unpubl.

DBASE IV

1988. Ashton-Tate Corp. Torrance, GA.

EYRE, F. H. (ed.)

1980. Forest Cover Types of the United States and Canada. Washington, D.C.: Soc. Amer. Foresters.

GRIFFIN, J. R. and W. B. CRITCHFIELD

1972. The distribution of forest trees in California. Research Paper PSW-82. Berkeley, CA: USDA Forest Service, Pacific Southwest Forest and Range Exp. Sta.

GRIFFIN, J, R.

1973. Xylem sap tension in three woodland oaks of central California. Ecol. 54:152-59.

1977. Oak Woodland. In Terrestrial Vegetation of California. M. G. Barbour and J. Major (eds.). NY: John Wiley \& Sons.

HILL, M. O.

1979a. TWINSPAN, A FORTRAN program for arranging multivariate data in an ordered two-way table by classification of the individuals and attributes. Ithaca, NY: Cornell Univ. Ecology and Systematics.

1979b. DECORANA, A FORTRAN program for detrended correspondence analysis and reciprocal averaging. Ithaca, NY: Cornell Univ. Ecology and Systematics.

HOLLAND, R. F.

1986. Preliminary description of the terrestrial natural communities of California. Sacramento, CA: Calif. Resour. Agency, Dept. Fish and Game.

HOWITT, B. F. and J. T. HOWELL

1964. The vascular plants of Monterey County, CA: Wasmann J. Biology 22:1-184.

JENSEN, H. A.

1947. A system for classifying vegetation in California. Sacramento, CA: Dept. Fish and Game. 33:199-266.

MAYER, K. E. and W. F. LAUDENSLAYER, JR. (eds.)

1988. A Guide to Wildlife Habitats of California. Sacramento, CA: Dept. Forestry and Fire Protection.

MAYER, K. E., P. C. PASSOF, C. BOLSINGER, W. E. GRENFELL, and H. SLACK

1986. Status of the hardwood resources of California: a report to the Board of Forestry.

MCBRIDE, J. R.

1974. Plant succession in the Berkeley Hills, California. Madrono 22:317-80.

MUNZ, P. A. and D. D. KECK

1968. A California Flora and Supplement. Berkeley and Los Angeles: Univ. Calif Press. NORUSIS, M. J.

1986. SPSS/PC + for the IBM PC/X'T/AT. Chicago, IL: SPSS Inc.: A1-H10.

1988. SPSS/PC +. Advanced Statistics. Chicago, IL: SPSS Inc. 
PASSOF, P. C., W. J. CLAWSON, and E. L. FITZHUGH

1985. Preliminary guidelines for managing California's hardwood rangelands. Publication 21413. Oakland: Univ. Calif. Div. Agric. Nat. Resous.

PAYSEN, T., J. A. DERBY, H. BLACK, Jr., V. C. BLEICH, and J. W. MINCKS

1980. A vegetation classification system applied to southern California. Gen. Tech. Rep. PSW-45. Berkeley, CA: USDA Forest Service, Pacific Southwest Forest and Range Exp. Sta.

PFISTER, R. D. and S. F. ARNO

1980. Classifying forest habitat types based on potential climax vegetation. Forest Sci. 26:52-70.

POWELL, R.

1987. Electronic Data Processing Codes for California Wildland Plants. 2d ed. Davis: Univ. Calif.

RBASE

1985. RBASE 5000. Bellevue, WA: Microrim Inc.

SCS

1981. Land resource regions and major land resource areas of the United States. Washington, D.C.: USDA Soil Cons. Srv. Agric. Hndbk. 296:11-14.

1986. Standard site component descriptions. Progress review for demonstration of the value and use of ecological concepts in forest and annual range sites. Yuba Co. Soil Survey. Aug. 11-13, 1986. Davis, CA: USDA Soil Cons. Srv.

THOMPSON, K.

1961. Riparian forest of the Sacramento Valley, California. Ann. Assoc. Amer. Geogr. 51:294-315.

WEISLANDER, A. E.

1935. A vegetation type map of California. Madrono 3:140-44.

WELLS, P. V.

1962. Vegetation in relation to geological substratum and fire in the San Luis Obispo Quadrangle, California. Ecol. Mono. 32:79-103.

The University of California, in compliance with Tides VI and VII of the Civil Rights Ad of 1964, Title IX of the Education Amendments of 1972, Sections 503 and 504 of the Rehabilitation Ad of 1973, and the Age Discrimination Act of 1975, does not discriminate on the basis of race, religion, color, national origin, sex, mental or physical handicap, or age in any of its programs or activities, or with respect to any of its employment policies, practices, or procedures. Nor does the University of California discriminate on the basis of ancestry, sexual orientation, marital staus, citizenship, medical condition (as defined in section 12926 of the California Government Code) or because individuals are special disabled veterans or Vietnam era veterans (as defined by the Vietnam Era Veterans Readjustment Act of 1974 and Section 12940 of the California Government Code). Inquiries regarding this policy may be addressed to the Affirmative Action Director, University of California, Agriculture and Nawral Resources, 300 Lakeside Drive, 6th Floor, Oakland, CA 94612-3560. (510) $987-0097$.

2m-pr-9/91-LTE/PF 
the USDA Forest Service, Pacific Northwest Research Station in the 1970s and 1980s. The base information on species composition, percent cover by species, tree stand structure, and environment was collected on $1 / 5$-acre plots. Species cover was determined from a $33^{\prime}$ by 66' belt transect on each plot.

The classification structure was developed using TWINSPAN, a polythetic, divisive classification program developed by Hill (1979a). Further analyses were performed using DECORANA, and frequencies, regression, and analysis of variance. The information contained in the final type descriptions was developed from VTM data only.

The keys and type descriptions have been field tested and verified at several locations in the State, such as Hopland Field Station, Sierra Field Station, Hastings Reserve, and the San Joaquin Experiment Station. The tests were conducted by individuals familiar with hardwood rangeland ecosystems and those who were not. Ongoing use of the keys and descriptions in other parts of the State will provide information for further refinement of keys and descriptions. Additional information on potential productivity and response to management will be incorporated into the descriptions by users as they identify the types that they are working in by the classification subseries names.

\section{ACKNOWLEDGMENTS}

We would like to thank Irene Timossi, Ayn Martin, Wilde Legard, Stephanie Fulton, Gene Forsburg, Fred Hempel, Claudio Gonzales, Tom Jimerson, Chuck Bolsinger, David Lopez, Robert Powell, the Jepson Herbarium, James Bartolome, Mark Borchert, and the many field reviewers for their help through different phases of this research. The senior author would also like to thank David Diaz for providing useful insight, criticism, and laughter at almost all the appropriate times. Funding was provided by the California Department of Forestry and Fire Protection (contract 8CA63912) as part of the Integrated Hardwood Range Management Program. 


\section{HILGARDIA Editorial Board}

\section{Edward S. Sylvester, Chairman, Berkeley}

(entomology, insecticides, ecology, environmental toxicology)

Peter Berck, Associate Editor, Berkeley (economics, statistics, resource management)

Harry W. Colvin, Associate Editor, Davis (animal science, physiology, breeding, zoology, genetics)

Donald J. Durzan, Associate Editor, Davis (tree fruit and nut crops)

Walter G. Jennings, Associate Editor, Davis (food science, nutrition, and chemistry)

John Letey, Associate Editor, Riverside (soils, plant nutrition, agronomy, agricultural engineering, water)

Irwin P. Ting, Associate Editor, Riverside (botany, plant physiology, biochemistry)

Betsey Tabraham, Acting Editor, Oakland

The Journal HILGARDIA is published irregularly. Number of pages and number of issues vary per annually numbered volume. Address: Agriculture and Natural Resources Publications, University of California, 300 Lakeside Drive, 6th Floor, Oakland, CA 94612-3550. 